\title{
The relationship between shrink-swell occurrence and climate in south-east England
}

\author{
Harrison, A.M., ${ }^{\text {a* }}$ Plim, J. ${ }^{\mathrm{a}}$, Harrison, M. ${ }^{\mathrm{a}}$, Jones, L.D. ${ }^{\mathrm{a}}$ \& Culshaw, M.G ${ }^{\mathrm{ab}}$. \\ ${ }^{a}$ British Geological Survey, Keyworth, Nottingham. NG12 5GG, UK \\ ${ }^{\mathrm{b}}$ School of Civil Engineering, University of Birmingham, Edgbaston, Birmingham B15 2TT, UK \\ *Corresponding author: Anna M Harrison. Email: amja@bgs.ac.uk Phone: 01159363230
}

\begin{abstract}
Climate change is one of the biggest environmental problems that the UK faces. Increased understanding of the impacts is vital to enable adaption to, and mitigation of, the consequences. This analysis and modelling of the relationship between climate and shrinkswell behaviour has been carried out to increase understanding of the potential consequences of changes in precipitation and temperature on ground movement in the south-east of England during the coming century.

Analysis of historical climate data, and comparison with subsidence claims data, demonstrated the relatively close relationship of subsidence with two years' previous precipitation. Boundaries are identified, with precipitation above $394 \mathrm{~mm}$ for the previous two years, leading to a lower level subsidence claims, and below 350 $\mathrm{mm}$ leading to a higher incidence. Combined with this inverse relationship, a direct relationship with temperature is identified, with a rise above $22.6^{\circ} \mathrm{C}$ in the mean maximum temperature for an accounting quarter leading to a peak in claims.
\end{abstract}

To model a projection for susceptibility of south-east England to future climate change, UKCIP02 forecast climate data were used, and combined with the British Geological Survey national shrink-swell GeoSure geohazard dataset. Preliminary results demonstrate the most noticeable increases in subsidence susceptibility are within the areas underlain by the London Clay formations, with other clay-rich formations also being identified, including glacial till.

Despite this being a preliminary model, with large amounts of future work identified, these results are significant, providing an insight into areas of higher susceptibility and the potential for changes in ground movement for the coming century.

Keywords: Shrink-swell, subsidence, precipitation, temperature, GIS

\section{INTRODUCTION}

For over 10 years, the British Geological Survey (BGS) has been investigating geotechnical and mineralogical factors controlling volume change behaviour of UK clay soils and mudrocks (for example, Gault Clay (Hobbs and Jones, 1998), the Mercia Mudstone Group (Jones and Hobbs, 1998), the Lambeth Group (Jones and Hobbs, 2005), the Lias Group (Hobbs et al., 2007) and the London Clay (Jones and Terrington, 2011). Investigation of the Wealden Group is underway. A strong understanding of the relationship between the 
geotechnical parameters and the shrink-swell susceptibility of clay has been developed (Hobbs and Jones, 2000; Jones, 2004). However, this research assumes steady-state climatic conditions. Similarly, the BGS's geohazard susceptibility datasets, such as GeoSure (Harrison et al., 2009; Walsby, 2008), have been developed without considering the effects of longerterm changes in precipitation or temperature arising from climate change. In response to the concerns expressed by the users of these BGS datasets and a general increased awareness that climate change is now one of the biggest environmental issues that the UK faces (UKCIP, 2009a), a study of the relationship between climate change and shrink-swell behaviour has been carried out.

In the UK, some Mesozoic and Tertiary clay soils and weak mudrocks, including the London Clay, are susceptible to shrinkage and swelling as environmental conditions change. These volume changes can cause enough ground movement to damage the foundations of some light structures such as houses. This damaging movement often results in subsidence insurance claims (Crilly, 2001). Shrink-swell susceptible clays change volume in response to variation in moisture content, particularly in the upper two metres, or so, of the ground. Ground moisture content variations are related to a number of factors, including weather and vegetation (e.g. growth or removal of trees), as well as anthropogenic factors such as road construction or paving, which reduces the amount of moisture entering the ground (Jones, 2002, 2004). Indications are that climate change will increasingly alter the moisture conditions that UK soils experience. For example, hotter, drier summers are predicted for the south-east of England, including the areas underlain by London Clay, together with milder, wetter winters (UKCIP, 2009a). Therefore, the occurrence or magnitude of damage to houses, commercial buildings and roads due to shrink-swell may change.

Information on subsidence insurance claims, provided by the Association of British Insurers (ABI), historical climate station data from the UK Meteorological Office (UKMO) and future climate change scenarios from the UKCIP02 climate data (temperature and precipitation) (UKCIP, 2002) have been combined with the BGS's GeoSure national geohazard data (Harrison et al., 2009; Walsby, 2008), to build a preliminary GIS model of how the susceptibility to swell-shrink might change as a result of predicted climate change scenarios. Using the generally agreed understanding that London Clay is highly susceptible to shrink-swell (Jones and Terrington, 2011), this research focuses initially on the London Clay, referred to as the test area (Harrison et al., 2010). Where patterns have been identified and relationships understood, these have been applied to the bedrock geology of the south-east of England, referred to as the model area. This paper describes the methodology developed and analysis of the data, and presents the results of initial modelling taking further those described by Harrison et al. (2010). Future work for model refinement is also discussed. 


\section{THE DATASETS}

\subsection{Insurance claims data}

Subsidence is the term used by the British insurance industry to group insurance claims arising from ground movement, whatever the cause. However, the vast majority of subsidence claims are the result of the shrinkage or swelling of clay soils. In this paper the term subsidence has been used to cover the effects of shrinkage and/or swelling of clay soils. Quarterly domestic subsidence claims data are available from the Association of British Insurers (ABI), for the period 1987 to 2008. The data are provided in terms of the number of claims for losses caused by ground movement (subsidence) between 1991 and 2008, and the gross incurred value of claims ( $£$ m) from 1987 to 2007. For the purposes of this study, the monetary value has been adjusted to take into account inflation using the Retail Price Index (RPI) calculated by the Treasury (the UK's Ministry of Finance), therefore allowing comparisons between years (Figure 1). These adjusted monetary values have been used to identify trends in the data as they provide an indication of the severity of the subsidence (i.e. more severe shrink-swell causes more building damage).

The annual monetary value of claims for 1975 to 2004, also available from ABI (ABI, 2009) compared with the number of claims notified in Figure 2, show an increase in claims from the mid 1980s onwards, with more distinct peaks and troughs post 1988. There could be a number of reasons for these variations in claims. Firstly, as shown in Figure 2, the most likely fundamental factor is climate related with precipitation and temperature conditions becoming more favourable (i.e. an increased range in rainfall and temperature) for the shrinkage and swelling of clay soils over the last 30 years (Pugh, 2002). Secondly, both Biddle (1979) and Rex and Thomas (2007) noted a change in attitude by householders during the 1970s in relation to insurance claims for subsidence. This may have been because home insurance did not include subsidence as a risk until 1971 (Wyles, 1983). The drought of 1976 heightened awareness and in following years there has been a general increase in recorded claims and annual fluctuations. Also, damage caused by subsidence is often discovered only during a house survey, carried out for a house sale. House sales tend to be more numerous during a strong economic climate such as before about 2008. Further, between August 2007 and May 2010, these surveys were carried out before the house was put on the market, as part of the Home Information Packs (HIP), rather than after an offer had been made on the property. Due to housing demand in the UK, there is an increasing pressure to develop land for houses on ground previously considered unsuitable due to geohazard susceptibility such as flooding and subsidence. The construction methods are adapted for these buildings to reduce the effect of these hazards, but if not sufficiently engineered, this could affect levels of insurance claims. Variations in groundwater rebound associated with extraction and recent changes in groundwater management may also have an influence on the number of subsidence claims. Other potentially influencing factors include changes in constructions methods, changing building quality and cost varying due to the economic climate, the effects of the media on public awareness, insurance advertising and, lastly, an overall larger number of people taking out home insurance due to increased housing stock. 
Against these reasons for an increasing level of claims, a number of factors might counteract the trend. First, the number of properties with vulnerability to subsidence would be expected to fall within the UK following around 40 years of insurance cover enabling claims for subsidence to be submitted and remedial work to be carried on damaged properties. Second, building standards with regard to foundation design to resist swell and shrinkage have been improved since the importance of swelling and shrinkage for foundation movement in the UK was first identified in the 1940s. For example, Anon (Anon, 1980, 1993a), recommended a minimum foundation depth of $0.9 \mathrm{~m}$ where only minor vegetation is present and Hunt et al. (1991) and Anon (1993b) discussed the use of underpinning, particularly where foundation movement has been experienced. The effect of trees in proximity to buildings on shrink-swell susceptible soils was discussed by Anon (1999). Research at the Building Research Establishment was subsequently incorporated into guidance provided by the National HouseBuilding Council (Anon, 1988, 2011). Driscoll and Skinner (2007) produced a comprehensive guide to good practice with regard to subsidence and domestic buildings and Jones and Jefferson (2012) have summarised many aspects of expansive soils including a range of foundation options.

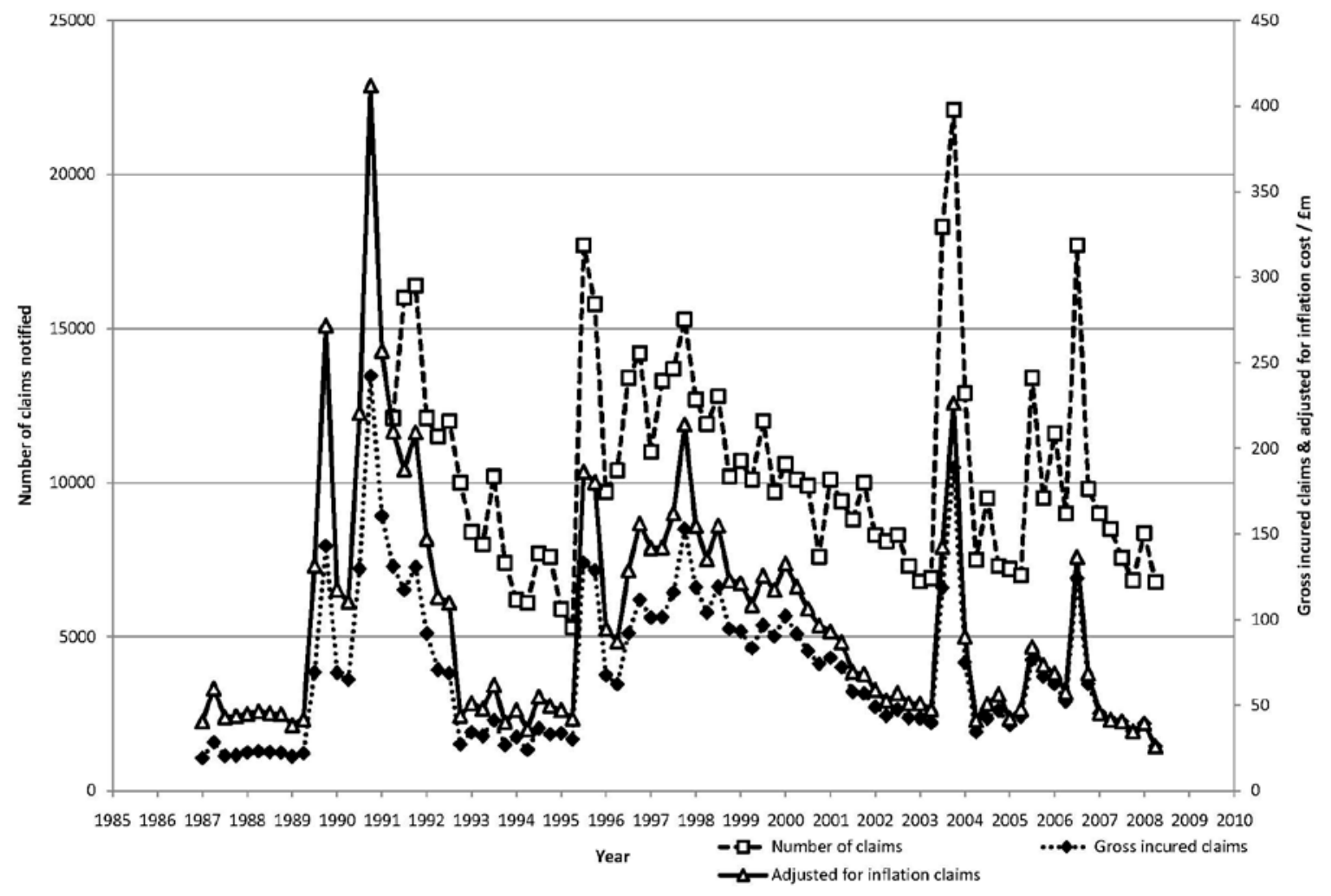

Figure 1 Comparison of total number of claims notified and gross incurred value of claims (with and without inflation) for quarterly domestic subsidence claims from 1987 to 2008. (Source: ABI) The graph shows a relatively close relationship between total number of claims and gross incurred value, both of which show the same general peaks and troughs over the test period. 


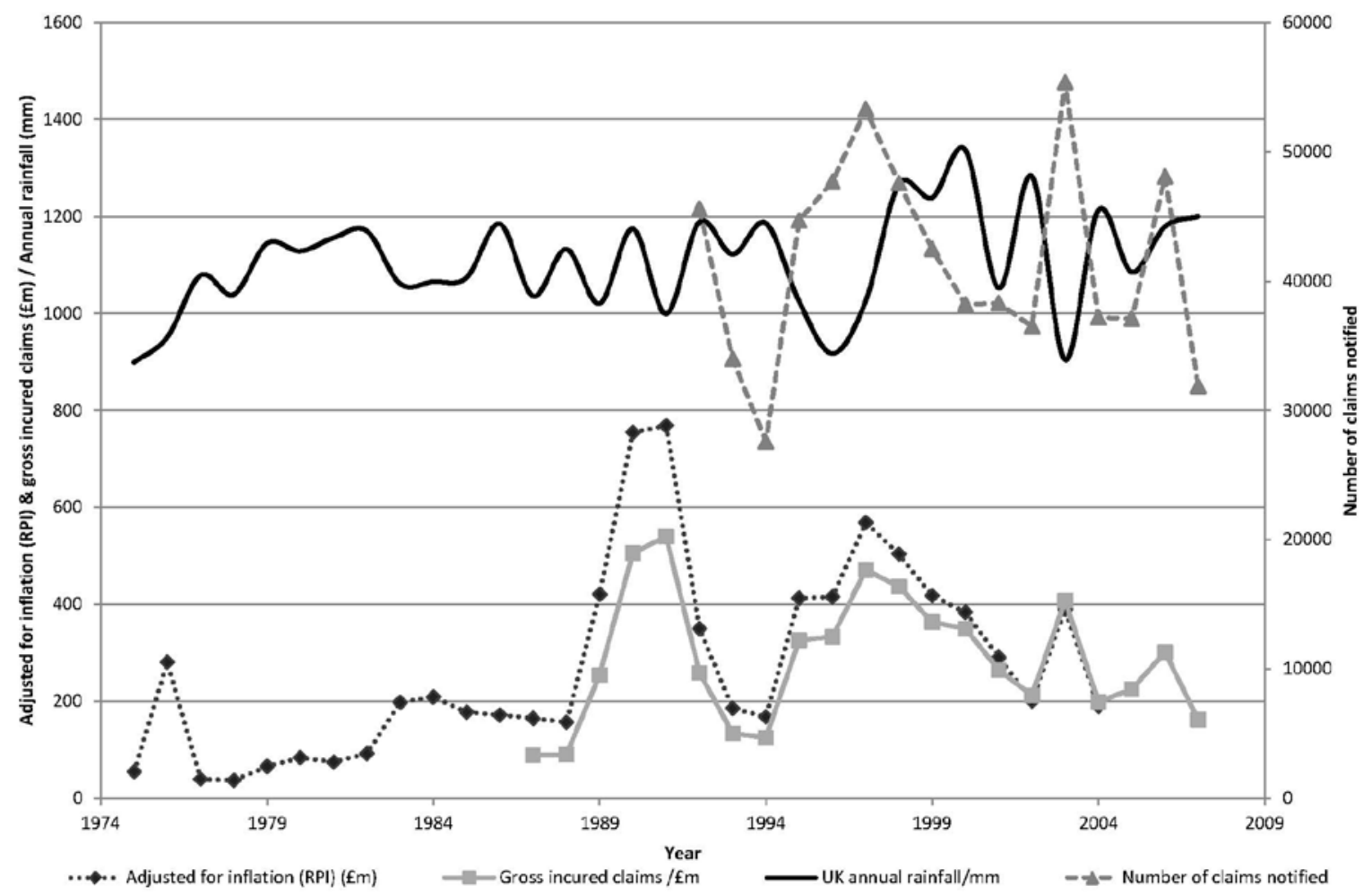

Figure 2 Comparison of total number of claims notified, gross incurred value of claims (with and without inflation) for yearly domestic subsidence claims from 1975 to 2008 and annual UK rainfall. (Sources: ABI \& Met Office) The graph shows a general increase in claims, with increased variation in annual claim value after 1988. Contains public sector information licensed under the Open Government Licence v1.0.

\subsection{GeoSure}

Since 2002 the British Geological Survey has been developing $25 \mathrm{~m}^{2}$ effective pixel size, highresolution national-scale models of natural geohazard susceptibility in Great Britain (GB), known as GeoSure (Harrison and Foster, 2003; Harrison et al., 2009; Walsby, 2007, 2008). These models have been created using a multi-criterion approach in a geographical information system (GIS) (ESRI ArcGIS 9.3). The GeoSure models consist of six data layers that identify areas of potential hazard in Great Britain (arising from shrink swell, landslides, dissolution of more soluble rocks, compressible ground, collapsible deposits and running sand). Each layer has national (GB) coverage. The GeoSure shrink-swell model has been used to provide geohazard susceptibility information in GIS format (Figure 3). The initial bedrock geological map for the south east of England, from which the GeoSure data are derived is shown in Figure 4. A thorough and up-to-date review of the geological setting of the London area can be found in Royse et al. (2011).

GeoSure provides geology-derived information on present day geohazard susceptibility. It is based on current climate conditions and does not take into account future climate variability. 


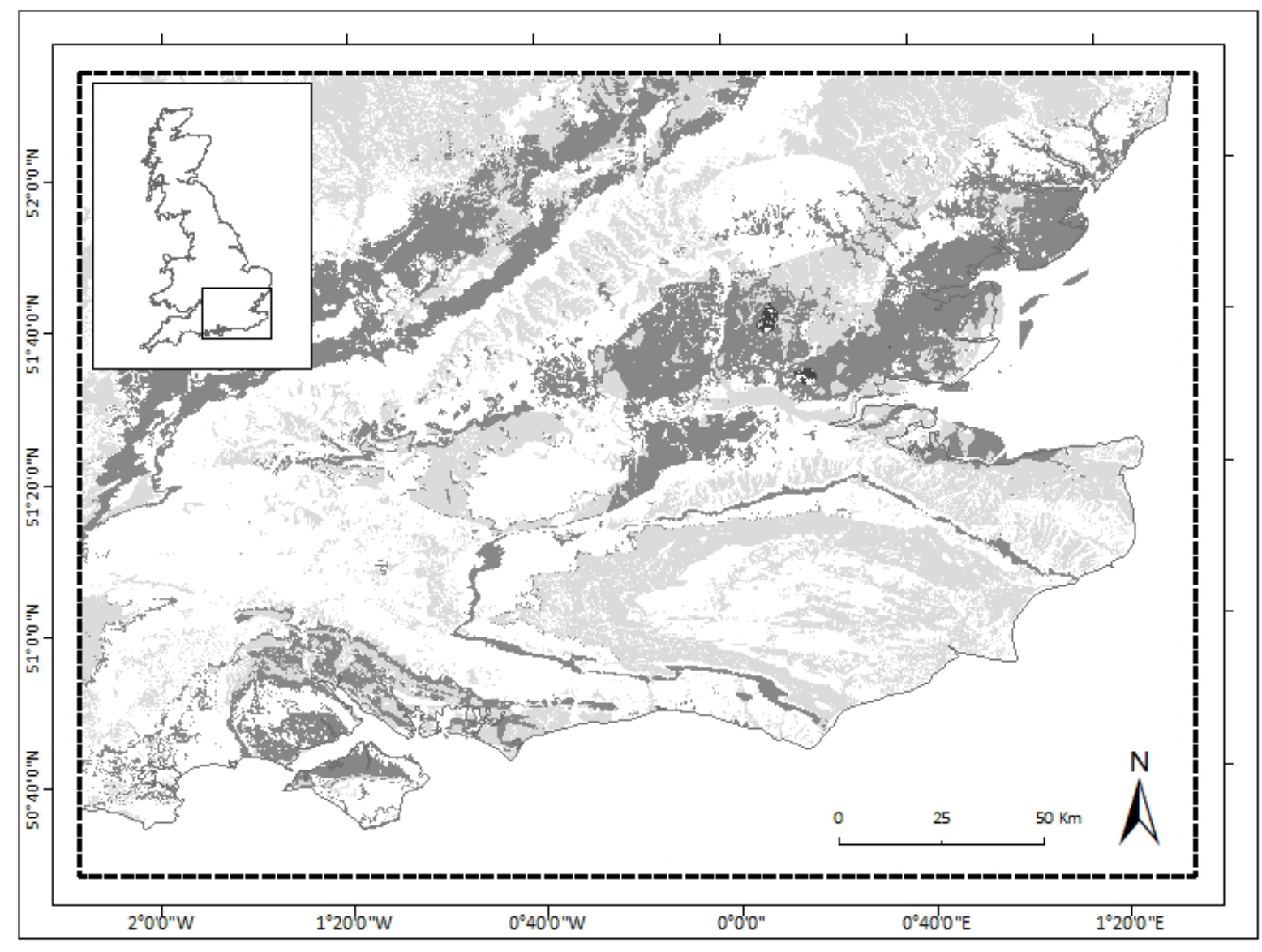

GeoSure shrink-swell rating

$3(\mathrm{C})$ - Ground conditions predom inantly medium plast icity.

4 (D) - Ground conditions pre dom inantly high plast icity.

5 (E) - Ground conditions predom inantly very high plasticity.

Figure 3 Simplified BGS GeoSure shrink-swell susceptibility map for the south-east England model area

BGS @ NERC All rights reserved. 


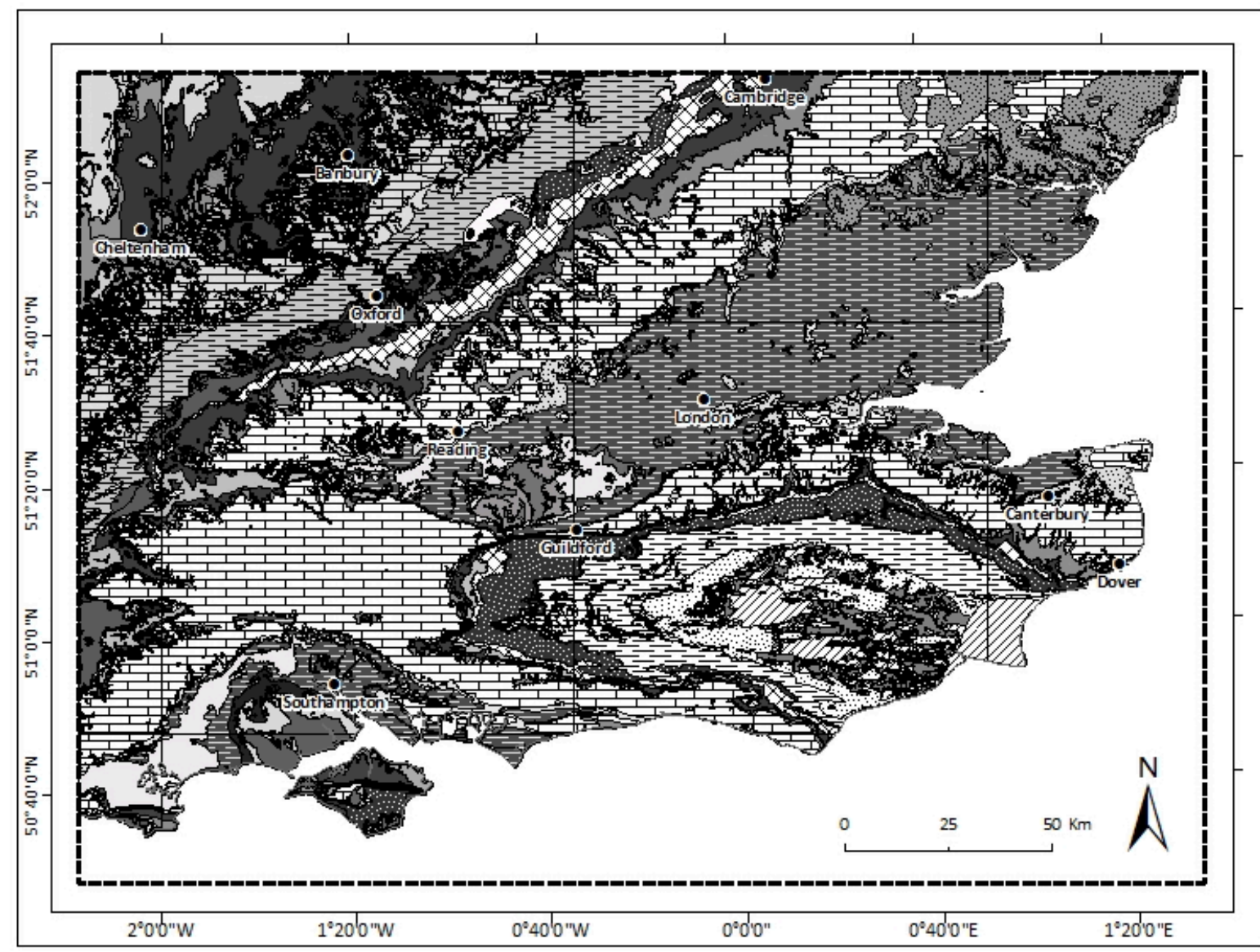

Main Geological Formations

$\square 7$ Ashdown Formation

$\bigotimes$ Gault Formation

London Clay Formation

Tunbridge We lls Sand Formation

Great Oolite Group

Lower Greensand Group

尼Upper Chalk Formation

Kellaways \& Oxford Clay Formation

Norwich Crag Formation Weald Clay Formation

Thanet Sand Formation

\section{Figure 4 Bedrock geology of the south-east of England (superficial deposits not shown)}

BGS (C) NERC All rights reserved.

\subsection{Historical climate data}

Historical (observed) data from three UKMO meteorological stations have been used for this modelling (Met Office, 2009) A total of three UKMO stations lie within, or close to, the London Basin (at Greenwich, Heathrow and Manston). The stations were selected as they are the closest to the London Clay outcrop, near to the London Basin, and are, thus, the most representative in terms of data on the climate affecting the London Clay. The locations of these stations are shown in Figure 5. The model area is an region with generally low rainfall compared with the rest of the UK (Met Office, 2011), with no areas of significantly high altitude affecting rainfall distribution. Monthly precipitation and temperature values for the model area have been calculated using the average of the mean monthly values for the three stations. As there is limited variability of climatic factors across the London Clay outcrop area, these monthly mean data values are considered sufficient for modelling purposes. 


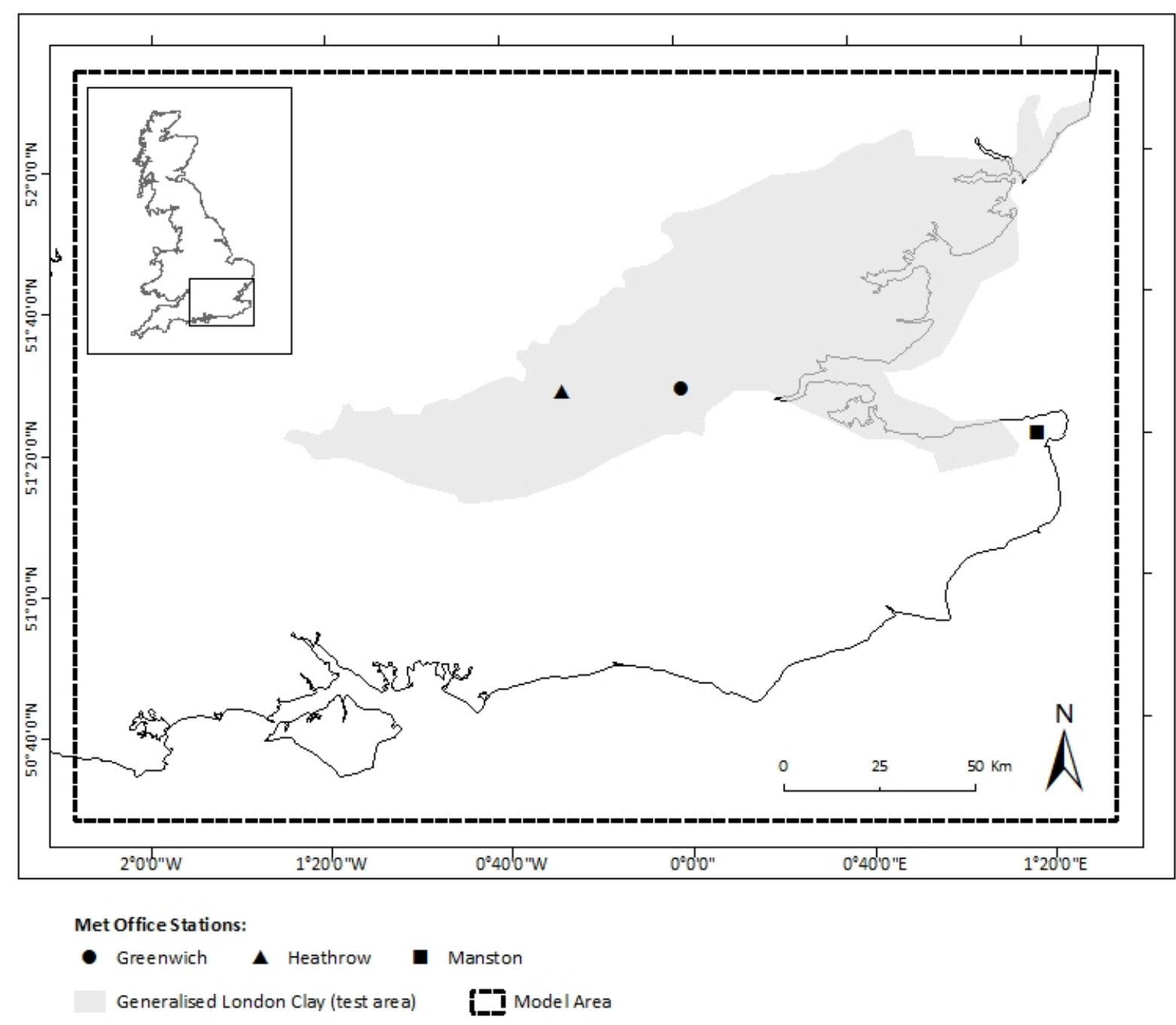

Figure 5 London Clay test area, model area and UKMO station locations

BGS () NERC All rights reserved.

\subsection{Forecast climate data}

The United Kingdom Climate Impacts Programme (UKCIP, 2009a) assesses the effects of the changing climate on various parts of the UK. Its website provides datasets and information to help improve understanding of climate change and how these changes might affect the UK.

The fourth emissions scenarios dataset (UKCIP02), released in 2002 (UKCIP, 2002), provided climate change scenarios at a much improved spatial resolution, compared with preceding scenarios: CCIRG91, CCIRG96 and UKCIP98. The fifth generation of climate scenarios, UKCIP09 projections (UKCIP, 2009a) employs new techniques relating to spatial resolution, modelling processes, outputs and delivery. Based on the increased knowledge and understanding, as well as the additional climate change data, it would be preferable to use the UKCP09 emissions scenarios for subsidence susceptibility projections. However, at the time this research was carried out, the data available through UKCP09 was of a coarser resolution than the UKCIP02 data and it was not possible to download it in the required format for 
combining with the GeoSure dataset. As a result, it was decided to continue with the use of the UKCIP02 dataset for this research.

UKCIP02 provides seasonal and annual average climate predictions based on four greenhouse gas emission rates. These four rates, known as scenarios, are low, medium-low, medium-high and high. Predicted changes in climate are provided for each of these scenarios, for three 30 year time periods. These are the 2020s (2011-2040), 2050s (2041-2070) and 2080s (2071-2100). The changes in climate for each of these periods are calculated as the change in 30-year average climate with respect to the model-simulated climate of the baseline period, 1961 to 1990 (Hulme et al., 2002). The UKCIP02 data used were the grid of 5km² pixel resolution precipitation and maximum temperature data. Data for the 2020s and 2080s high and low emissions scenarios were utilised (UKCIP, 2002). These scenarios were selected as they represent the shortest and longest projections currently available, and the highest and lowest emissions outputs, thus providing a good indication of the breadth in potential variability in the impacts of a changing climate.

\subsection{Comparison of datasets}

Because the insurance claims data are only available quarterly, climate data based on these quarters have been used to enable direct comparison of trends. The quarters of the year in which the insurance data have been provided by the ABI are not ideal for comparison with climate data. This is because the claims data are provided for each quarter beginning in January whereas climate data are better used in relation to the seasons. This results in a one month shift between the two datasets being used for modelling, as shown in Table 1.

\begin{tabular}{|c|c|c|c|}
\hline Quarter name & Quarter label & Months in climate quarter & Months in claims quarter \\
\hline Winter & Q1 & December, January, February & January, February, March \\
\hline Spring & Q2 & March, April, May & April, May, June \\
\hline Summer & Q3 & June, July, August & July, August, September \\
\hline Autumn & Q4 & $\begin{array}{c}\text { September, October, } \\
\text { November }\end{array}$ & $\begin{array}{c}\text { October, November, } \\
\text { December }\end{array}$ \\
\hline
\end{tabular}

Table 1 Climate and claims data quarters 


\subsection{Assumptions}

To analyse the datasets and build a good understanding of the relationships between these datasets, some assumptions were applied for the London Clay test area:

- All subsidence claims originate from within the area underlain by London Clay (called the 'test area').

- Value of claims ( $£$ ), adjusted by the RPI, represents subsidence occurrence within the test area (the area underlain by London Clay).

- Houses are evenly distributed within the London Clay test area (this is a preliminary assumption, which will be refined in future models).

- The distribution of claims is uniform across the London Clay test area (this is a preliminary assumption, which can be refined in future models).

- Rainfall and temperature are controlling factors of ground moisture conditions. The presence of different types of vegetation will influence subsidence claims, therefore this is a preliminary assumption, which can be refined in future models.

- The average temperature and precipitation data from the three meteorological stations is representative of the test area.

- There is only a short lag-time in the main effects of shrink-swell occurring (e.g. cracks noticed in houses).

- An insurance claim is made within a couple of months of the housing damage being noticed.

- The model does not account for areas covered by superficial Thames terrace gravels where claims and subsidence are reduced.

These assumptions were used to analyse the London Clay test area. By making these assumptions, focusing on the highly susceptible London Clay, utilising only the precipitation and temperature from within the London Clay test area, and identifying relationships with the claims data, enabled rules to be constructed and applied across south-east England for the final model output. 
3.2 Average Rainfall and adjusted claims

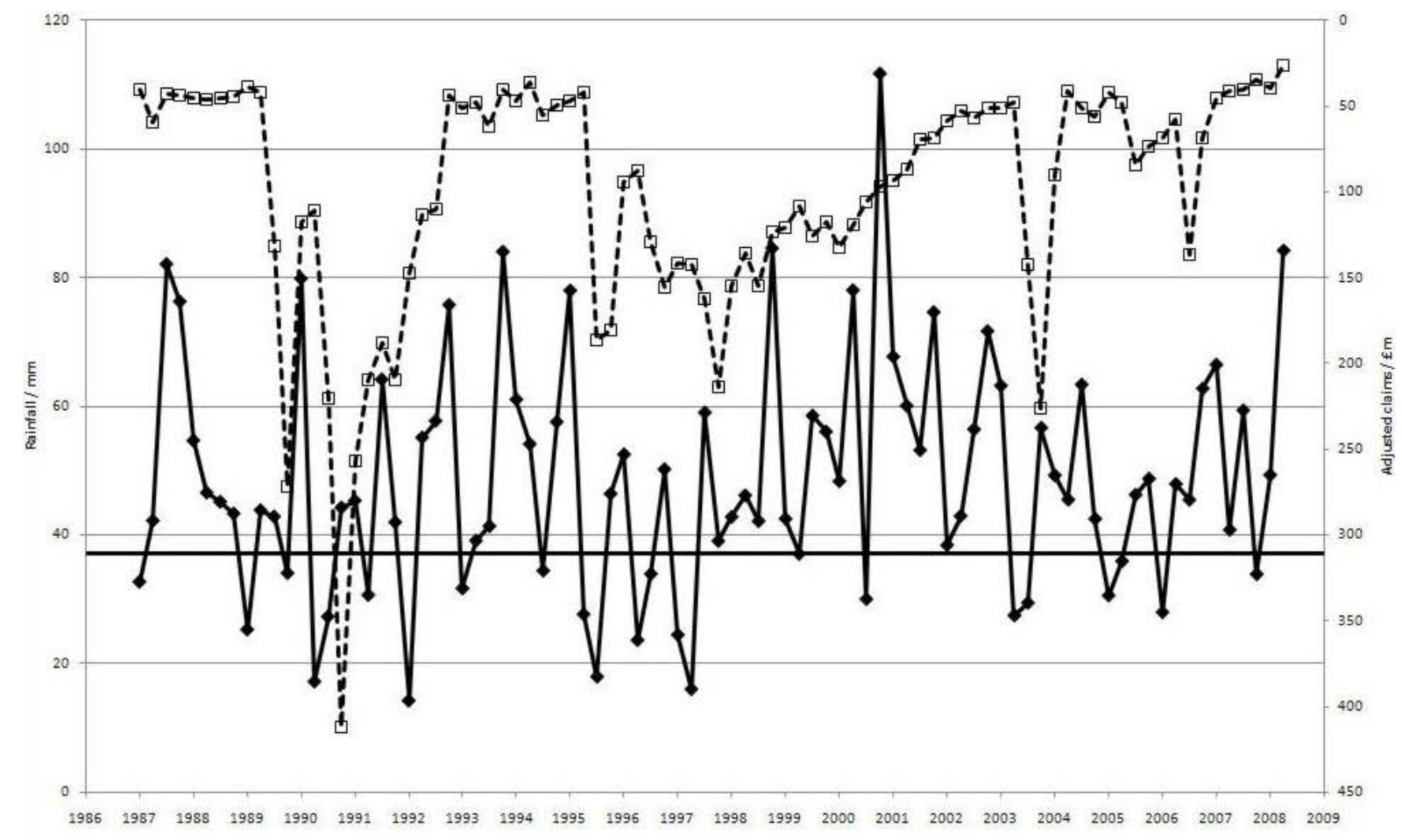

Figure 6 Average rainfall per month in quarter compared to insurance claims 1987 to 2008 (claims plotted inversely). Contains public sector information licensed under the Open Government Licence v1.0.

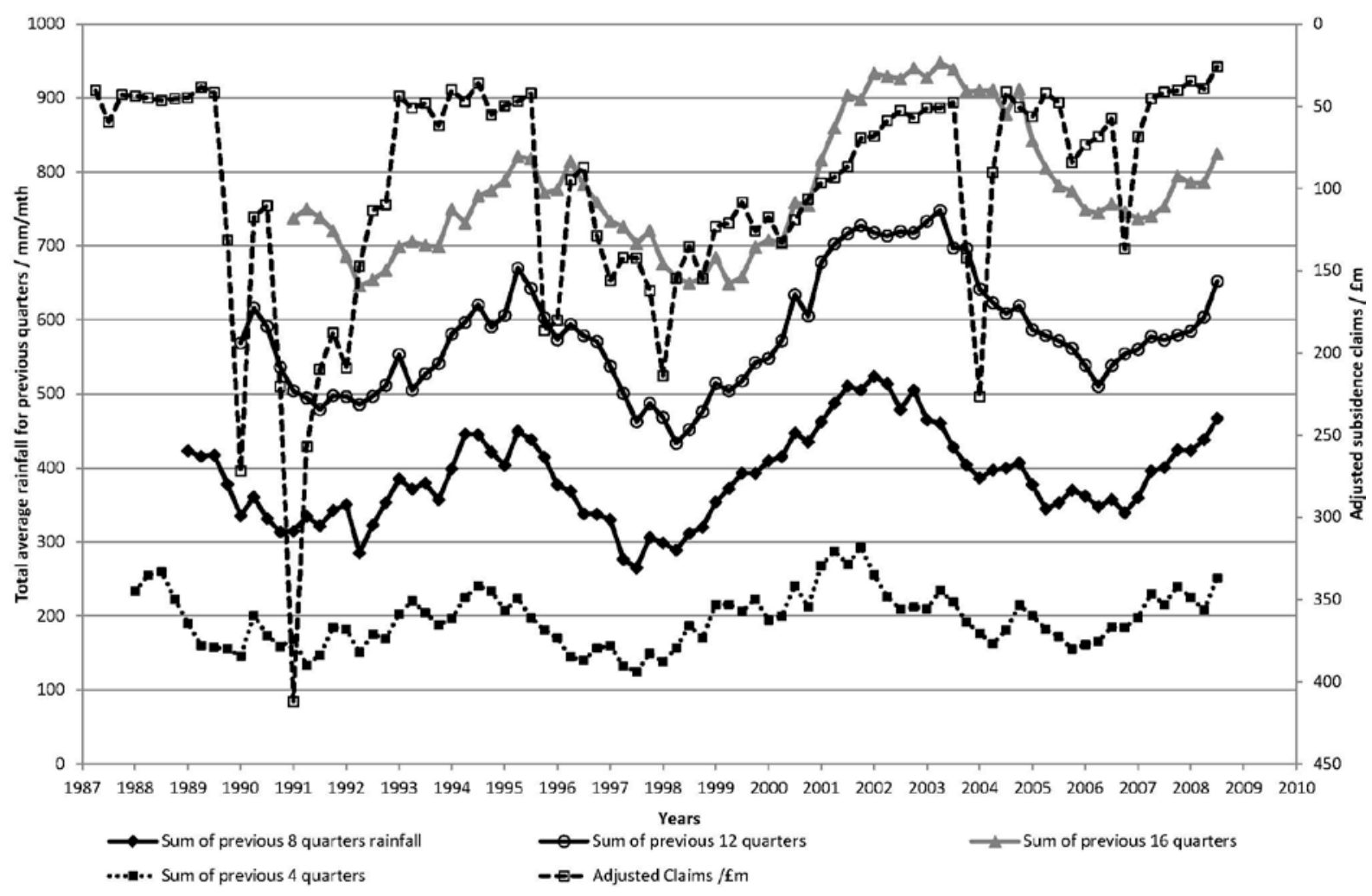




\section{Figure 7 Previous rainfall (for 4, 8, 12 and 16 previous quarters), and adjusted subsidence claims (claims plotted inversely). Contains public sector information licensed under the Open Government Licence v1.0.}

Throughout, insurance claims data have been plotted inversely to emphasise where troughs in rainfall coincide with peaks in subsidence claims.

Figure 6 shows that generally major troughs in quarterly average rainfall result in an increase in subsidence claims. This can be seen, particularly, for the period between 1990 and 1991 where the second quarter of 1990 had $17 \mathrm{~mm}$ average rainfall, which is then followed by a peak in claims of $£ 412 \mathrm{~m}$ in the final quarter of 1990 . Minor troughs in average rainfall per quarter are also followed by minor peaks in subsidence claims. In broad terms, a drop below approximately 37mm (the horizontal line) in rainfall, leads to a peak in shrink swell insurance claims, but this provides no indication of how large this peak will be.

An exception to this relationship can be seen within the 2000-2001 period where a moderate trough in rainfall in the third quarter of 2000 does not result in a peak in claims. Instead, a significant peak in rainfall immediately follows in the fourth quarter, which has the effect of cancelling out the previous low. This influence of previous quarter's rainfall over subsidence claims indicates the importance of ground saturation before the addition of fresh rainfall. This suggests investigating the sum of rainfall of previous quarters, thus taking into account the gradual increase or decrease of ground moisture conditions, for which, in this research, rainfall is being used as a proxy.

Figure 6 also demonstrates that there is a lag time between periods of low rainfall and peaks in claims. Only 1 or 2 quarters after a dry quarter (3 to 6 months), a peak in claims can often be seen, such as 1990 and 1995. Another detail shown by Figure 6 is the affect dry periods can have on a period of generally falling claims. For example, the dry spell in winter 1992 has an associated 'shoulder' in the falling number of claims, just 3 to 6 months later, indicating increased claims caused by the dry winter, even though no actual "peak" is revealed by the data.

Additionally, Figure 6 shows the limitations of using only one quarter's rainfall as a simple indicator of shrink-swell occurrence. In 1987 the driest quarter with rainfall of 33mm, has an associated peak in claims of $£ 60 \mathrm{~m}$, during the following quarter. In contrast, the driest quarter in 1991, with rainfall of $31 \mathrm{~mm}$ has a related peak in insurance claims of $£ 188 \mathrm{~m}$. This $£ 128 \mathrm{~m}$ difference indicates a more complex relationship. This needs to be investigated further to understand the levels of rainfall required to induce a certain value of shrink swell insurance claims; that it leads to a peak in claims is not enough.

As shown in Figure 7, increasing the number of quarters included in the summation appears to better fit the inverse correlation with insurance losses. Figure 7 shows two, three and four years of previous rainfall plotted with adjusted claims. Perhaps not surprisingly, looking at more than two years previous data seems to cause too much 'smoothing' of the resulting plots. It was also found that when the sum of the previous quarter's rainfall was not made up 
of whole years (multiples of four quarters) the plots produced were much nosier as it became biased by the seasonal quarter that was most abundant within those summed. Visually, the sum of the previous eight quarters (two years) appears to provide the best comparison with the adjusted claims data.

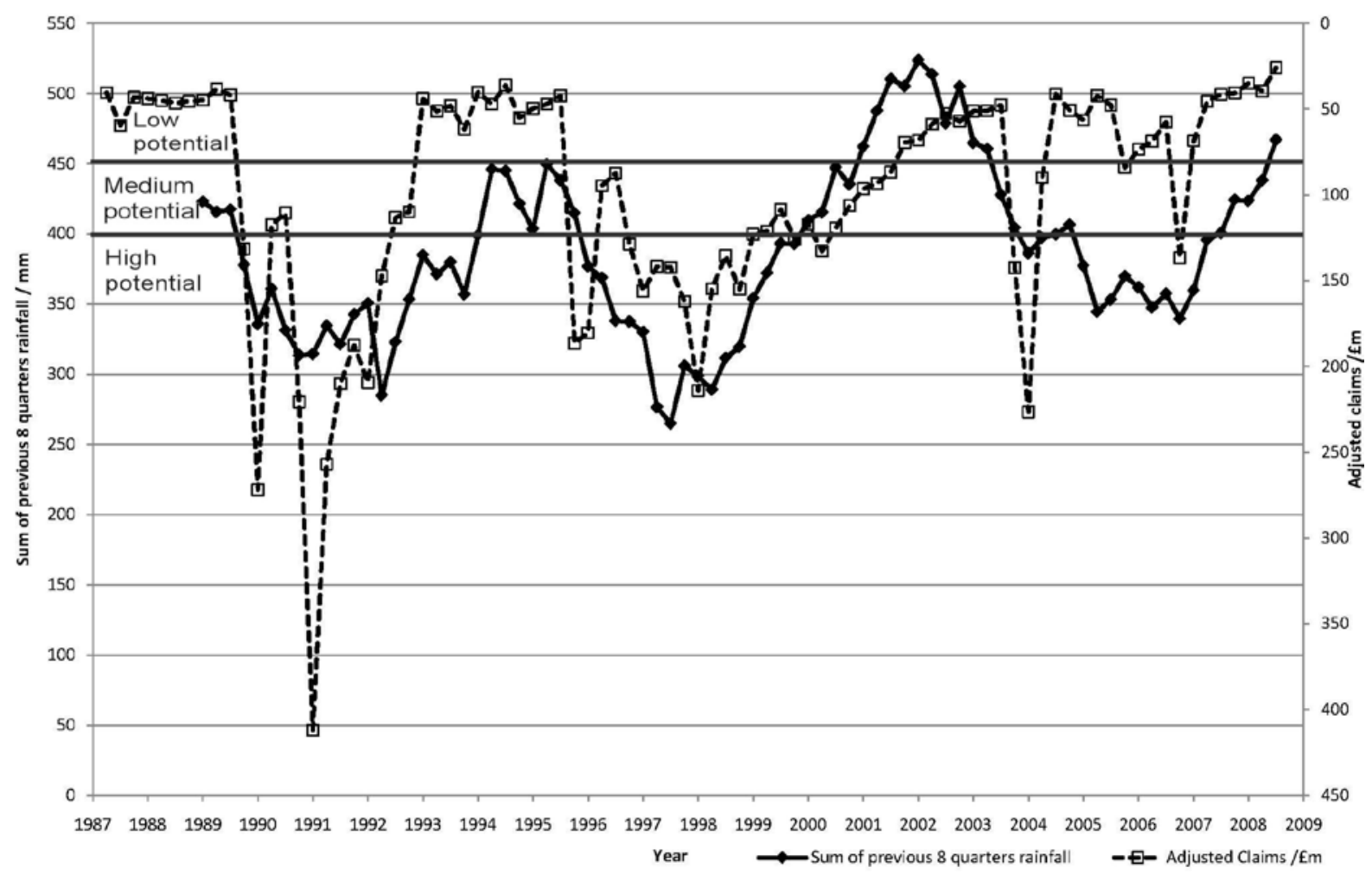

Figure 8 Sum of 2 years previous average quarterly rainfall and adjusted subsidence claims (note claims values plotted inversely). Contains public sector information licensed under the Open Government Licence v1.0.

Figure 8 is a plot of the sum of the rainfall for the preceding eight quarters period and the value of insurance claims against time plotted inversely. It demonstrates a correlation between low levels of preceding rainfall and increased value of subsidence claims. The rainfall amount has been divided into three classes that correspond with high, medium, and low potential of subsidence resulting from shrink-swell. Based on this graph, as initial classifications, summed rainfall values above $450 \mathrm{~mm}$ are classed as low potential and those below $400 \mathrm{~mm}$ are classed as high potential.

\subsection{Average Temperature and adjusted claims}

On Figure 8, there are six large peaks in claims (appearing on the graph as troughs as the data are plotted inversely), that do not follow the same pattern as the rainfall data, thus suggesting that may not be solely controlled by the rainfall. Figure 9 shows the value of subsidence claims is also related to temperature variation. This might be expected because of the effects of evapo-transpiration during warmer weather.

\section{Term




\begin{tabular}{|c|c|c|}
\hline TMAX & $\begin{array}{l}\text { Maximum temperature recorded for that month. } \\
\text { For this analysis, this is the mean of the three } \\
\text { TMAXs recorded that month by the UKMO } \\
\text { stations. }\end{array}$ & $\begin{array}{l}\text { TMAX }=\left(\text { TMAX }_{\text {greenwich }}+\right. \\
\left.\text { TMAX }_{\text {heathrow }}+\text { TMAX }_{\text {manston }}\right) \\
/ 3\end{array}$ \\
\hline $\begin{array}{c}\text { Quarterly } \\
\text { Mean TMAX }\end{array}$ & $\begin{array}{l}\text { The mean of the } 3 \text { monthly TMAX values } \\
\text { provided for each quarter. }\end{array}$ & $\begin{array}{l}\text { Quarterly Mean TMAX = } \\
\left(\text { TMAX }_{\mathrm{mth} 1}+\mathrm{TMAX}_{\mathrm{mth2}}+\right. \\
\left.\text { TMAX }_{\mathrm{mth3}}\right) / 3\end{array}$ \\
\hline $\begin{array}{l}\text { Quarterly } \\
\text { Maximum } \\
\text { TMAX }\end{array}$ & $\begin{array}{l}\text { The highest value of the } 3 \text { monthly TMAX } \\
\text { values provided for each quarter. }\end{array}$ & $\begin{array}{l}\text { Quarterly Maximum TMAX = } \\
\text { highest value of } \text { TMAX }_{\mathrm{mth} 1} \text {, } \\
\text { TMAX }_{\mathrm{mth} 2} \text { and } \mathrm{TMAX}_{\mathrm{mth} 3}\end{array}$ \\
\hline
\end{tabular}

\section{Table 2 TMAX, mean TMAX and maximum TMAX calculations}

As shown in Figure 9, when the quarterly mean TMAX (Table 2) for the quarter is above $22.6^{\circ} \mathrm{C}$ (lower horizontal line), this corresponds to a peak in claims. As the quarterly mean TMAX takes into account all monthly values recorded for that quarter, it provides a good representation of the quarter's temperatures. Therefore, a quarter with 3 months of higher temperatures will produce an output value higher than those containing similar values plus a cooler month. So, periods of sustained average high temperatures could be detected in this way. This period of longer term higher temperatures can lead to higher evapo-transpiration rates leading to a decrease in soil moisture content, particularly if low rainfall is recorded at the same time.

There is also a strong correlation between quarterly maximum TMAX (Table 2) and claims, with a rise above $25.5^{\circ} \mathrm{C}$ (higher horizontal line) correlating with a claims surge. This is interesting as this is a one-off stand alone daily temperature, which does not represent the temperatures for the whole quarter. 


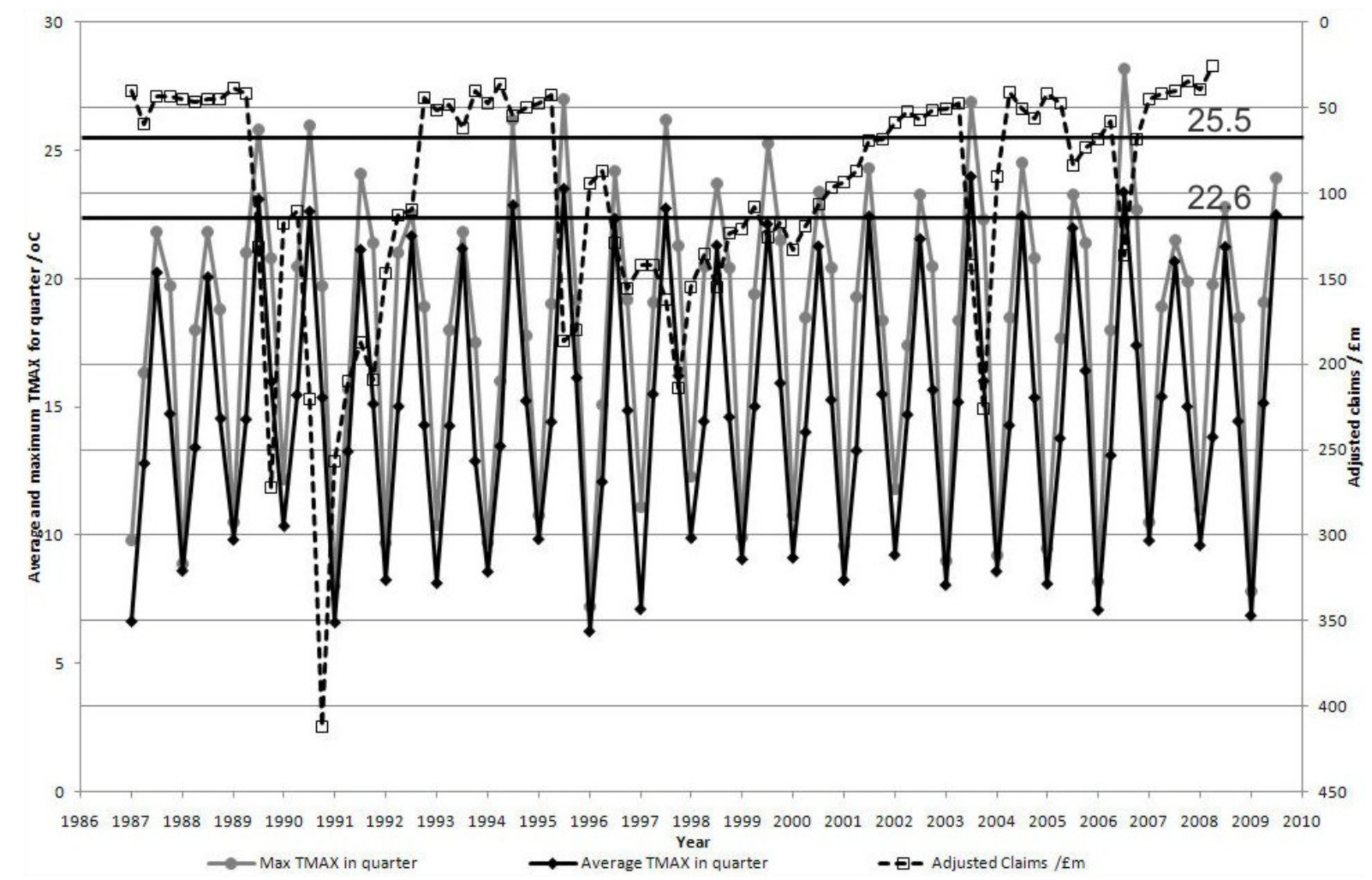

Figure 9 Quarterly mean TMAX (the mean of the 3 monthly TMAX values provided for each quarter) and quarterly maximum TMAX (The highest value of the 3 monthly TMAX values provided for each quarter) and subsidence claims. Contains public sector information licensed under the Open Government Licence v1.0.

It has long been recognised that there is a significant large-scale correlation between monthly mean temperature and precipitation (Madden and Williams, 1978). There is a strong negative correlation, with dry conditions favouring more sunshine and warmer weather, and wet summers being cooler, thus the relationship identified between rainfall and temperature is not a new one. However, this is a generalised correlation and the temperatures experienced with a certain rainfall can vary. For example, if the rainfall experienced on two separate days is the same, it does not mean that the temperature on those days was also exactly the same. Thus, it is important to look at temperature as an independent variable for this model. This analysis shows that once a 'tipping point' mean TMAX temperature is reached $\left(22.6^{\circ} \mathrm{C}\right)$, the two variables work together to produce a larger peak, to match the peak in adjusted claims. Analysed alone, the rainfall data underestimates the peak and does not correlate so closely with the adjusted claims data.

More laboratory research is required to investigate whether these values represent a threshold temperature at which the clay changes its properties and how the clay reacts to temperature change. 


\subsection{Combining the datasets}

Based on the analysis described above, rules have been identified for use in the preliminary model. Limit values have been allocated to the high, medium and low rainfall classes (Figure 8), and two temperatures classes have been defined (Figure 9).

The class limit values are outlined in Table 3.

\begin{tabular}{|c|c|}
\hline Parameter & $\begin{array}{c}\text { Initial Threshold Value } \\
\text { Rainfall (high potential) }\end{array}$ \\
$\begin{array}{c}\text { Below 400mm for the last } 8 \\
\text { quarters }\end{array}$ \\
\hline Rainfall (low potential) & $\begin{array}{c}\text { Above } 450 \mathrm{~mm} \text { for the last } 8 \\
\text { quarters }\end{array}$ \\
\hline Rainfall (medium potential) & $\begin{array}{c}\text { Between } 400 \text { and } 450 \mathrm{~mm} \text { for } \\
\text { the last } 8 \text { quarters }\end{array}$ \\
\hline Temperature (high potential) & Above $22.6^{\circ} \mathrm{C}$ for 1 quarter \\
\hline Temperature (low potential) & Below $22.6^{\circ} \mathrm{C}$ for 1 quarter \\
\hline
\end{tabular}

\section{Table 3 Initial threshold values for the model}

These class limit values have been combined with the GeoSure shrink-swell dataset, to provide a subsidence susceptibility rating in relation to climate.

\section{MODEL METHODOLOGY}

The climate scenario data from UKCIP02, the Met Office data and the GeoSure shrink-swell dataset were combined in a GIS to build the preliminary swell-shrink projection model.

The key datasets utilised in the preliminary model were the UKCIP02 25km² (5km x 5km) resolution precipitation and maximum temperature data for the 2020s and 2080s high and low emissions scenarios and the $625 \mathrm{~m}^{2}(25 \mathrm{~m} \times 25 \mathrm{~m})$ resolution GeoSure shrink-swell version 5 data. The GeoSure shrink-swell grid is made up of five values, as shown in Table 4.

\begin{tabular}{|c|c|}
\hline GeoSure Classification & $\begin{array}{c}\text { Volume Change Potential (shrink- } \\
\text { swell susceptibility) }\end{array}$ \\
\hline $1(\mathrm{~A})$ & Non Plastic \\
\hline $2(\mathrm{~B})$ & Low \\
\hline $3(\mathrm{C})$ & High \\
\hline $4(\mathrm{D})$ & Very High \\
\hline $5(\mathrm{E})$ & \\
\hline
\end{tabular}

Table 4 GeoSure shrink-swell classification 
The GeoSure shrink-swell gridded dataset was reclassified using the reclassify tool within ArcGIS to extract areas categorised as 3(C) to 5(E), thus removing those with a low potential to shrink or swell (Figure 3). The monthly UKCIP02 5km resolution data were downloaded as raw text files. To import these into the GIS as raster grids, an ASCII to raster conversion was performed using the conversion tool in ArcGIS. The monthly grids for precipitation and maximum temperature were then aggregated in accordance with Table 1 and divided by three to produce mean precipitation and maximum temperature grids for each quarter of the year. Therefore, for each scenario there were four precipitation grids and four maximum temperature grids representing an average for the whole of the 2020s or 2080s. To model the suggested rules outlined in Section 3.4, the four precipitation grids were added together and multiplied by two to represent the previous eight quarters.

\subsection{Model Implementation}

To apply the rules outlined in Section 3.4, a command line script was written to build a series of conditions using the single output map algebra function and conditional statement within ArcGIS, the structure of which is shown below:

\section{SingleOutputMapAlgebra "Con(<condition>,<true_expression $>,<$ false_expression $>$ )" outgrid}

The precipitation grids representing the previous eight quarters and the monthly temperature grids were used as inputs to the <condition $>$. The $<$ true_expression $>$ refers to the score given to each condition. An example of the full command line statement is given below, where PHI refers to the precipitation grids for the high emissions scenario:

$$
\begin{aligned}
\text { SingleOutputMapAlgebra } & \text { "Con }\left(\left[P H I \_2080 \_8 Q\right]<400,6,\left[P H I \_2080 \_8 Q\right]>450,1,\left[P H I \_2080 \_8 Q\right]\right. \\
& \left.>400 \&\left[P H I \_2080 \_8 Q\right]<450,3\right) " \text { grid1_PHI }
\end{aligned}
$$

Each cell in the input grid(s) was evaluated using the conditional statement. A score was then applied to the corresponding cell in the output grid depending on which condition was true. Using these conditional statements a grid was generated for each grid representing the eight previous quarters of precipitation. A score of 1, 3, or 6 was applied to each across the grid depending on whether the original value was greater than the high risk threshold, less than the low risk threshold, or lying between the two. The scores were weighted in this way to emphasize the distinction between cells falling into the different thresholds. For temperature, the conditional statement compared all four averaged quarterly temperature grids. If any cells in any of the four grids had an average temperature greater than $22.6^{\circ} \mathrm{C}$ then the corresponding cell in the output grid was given a value of 3 . If no cells in any of the four grids reached above $22.6^{\circ} \mathrm{C}$ then a value of 0 was applied to the corresponding cells in the output grid. Again, the scores were weighted in this way to create a clear distinction between cells falling above and below the threshold temperature. The output precipitation and temperature grids were then added together to generate a climate score grid (Table 5) with values ranging from 1 to 9 for each greenhouse gas emissions scenario in the 2020s and 2080s.

\begin{tabular}{|l|l|l|l|l|}
\hline Rainfall & Rainfall & Temperature & Temperature & Climate \\
\hline
\end{tabular}




\begin{tabular}{|l|l|l|l|l|}
\hline & Score & & Score & score \\
\hline $\begin{array}{l}\text { Below } 400 \mathrm{~mm} \text { for the last } 8 \\
\text { quarters }\end{array}$ & 1 & $\begin{array}{l}\text { Below } 22.6^{\circ} \mathrm{C} \text { for } 1 \\
\text { quarter (low) }\end{array}$ & 0 & 1 \\
\hline $\begin{array}{l}\text { Below } 400 \mathrm{~mm} \text { for the last } 8 \\
\text { quarters }\end{array}$ & 1 & $\begin{array}{l}\text { Above } 22.6^{\circ} \mathrm{C} \text { for } 1 \\
\text { quarter (high) }\end{array}$ & 3 & 4 \\
\hline $\begin{array}{l}\text { Between } 400 \text { and } 450 \mathrm{~mm} \text { for } \\
\text { the last } 8 \text { quarters }\end{array}$ & 3 & $\begin{array}{l}\text { Below } 22.6^{\circ} \mathrm{C} \text { for } 1 \\
\text { quarter (low) }\end{array}$ & 0 & 3 \\
\hline $\begin{array}{l}\text { Between } 400 \text { and } 450 \mathrm{~mm} \text { for } \\
\text { the last } 8 \text { quarters }\end{array}$ & 3 & $\begin{array}{l}\text { Above } 22.6^{\circ} \mathrm{C} \text { for } 1 \\
\text { quarter (high) }\end{array}$ & 3 & 6 \\
\hline $\begin{array}{l}\text { Above } 450 \mathrm{~mm} \text { for the last } 8 \\
\text { quarters }\end{array}$ & 6 & $\begin{array}{l}\text { Below } 22.6^{\circ} \mathrm{C} \text { for } 1 \\
\text { quarter (low) }\end{array}$ & 0 & 6 \\
\hline $\begin{array}{l}\text { Above } 450 \mathrm{~mm} \text { for the last } 8 \\
\text { quarters }\end{array}$ & 6 & $\begin{array}{l}\text { Above } 22.6^{\circ} \mathrm{C} \text { for } 1 \\
\text { quarter (high) }\end{array}$ & 3 & 9 \\
\hline
\end{tabular}

Table 5 The rainfall and temperature limits for assigning rainfall and temperature scores and the concluding combined climate scores

The output climate score grids were then combined with the GeoSure shrink-swell grid to produce final grids classifying the projected subsidence susceptibility across the model area under the climatic conditions predicted for high and low emissions scenarios of the 2020s and 2080s. However, before the grids could be combined, the rules grids were resampled to a cell size of $25 \mathrm{~m}$ by $25 \mathrm{~m}\left(625 \mathrm{~m}^{2}\right)$, the same as the GeoSure shrink-swell grid. A conditional statement was used to compare each cell in the climate score grid with the corresponding cell in the GeoSure shrink-swell grid. Table 6 shows the output values ('Output' column) given for each possible combination of values from the climate score grid ('Climate [temperature and rainfall] score' column) and the GeoSure shrink-swell grid ('GeoSure [shrink-swell] score’ column). The final output values were arrived at by considering the existing GeoSure score and how the associated climate score would impact upon that rating, they do not have a mathematical relationship, as detailed in Table 6. They were combined in this way, and given a susceptibility classification as such, as the areas of change in susceptibility need to be recognised in the output, and this needs to be related to the existing GeoSure value. Thus, the output score does not have a linear relationship to a higher susceptibility, but is related back to the existing GeoSure rating and is given a susceptibility classification of "remains", "raised" or "significantly raised" from the original GeoSure score. For example, if the GeoSure score is 3 and the climate score is 1 then the overall impact is going to be minimal, so an output score of 1 is applied and the Geosure rating will remain unchanged. However, a climate score of 6 or 9 could potentially have a significant impact and so a higher output value is applied. The final susceptibility grid has a possible value range of 1 to 9 labelled according to the 'Susceptibility Classification' column in Table 6. 


\begin{tabular}{|r|r|r|l|}
\hline $\begin{array}{c}\text { GeoSure } \\
\text { (shrink-swell) } \\
\text { score }\end{array}$ & $\begin{array}{c}\text { Climate } \\
\text { (temperature } \\
\text { and rainfall) } \\
\text { score }\end{array}$ & Output & Susceptibility Classification \\
\hline 3 & 1 & 1 & Remains medium \\
\hline 3 & 3 & 2 & Raised from medium \\
\hline 3 & 4 & 2 & Raised from medium \\
\hline 3 & 6 & 3 & Significantly raised from medium \\
\hline 3 & 9 & 3 & Significantly raised from medium \\
\hline 4 & 1 & 4 & Remains high \\
\hline 4 & 3 & 5 & Raised from high \\
\hline 4 & 4 & 5 & Raised from high \\
\hline 4 & 6 & 6 & Significantly raised from high \\
\hline 4 & 9 & 6 & Significantly raised from high \\
\hline 5 & 1 & 7 & Remains very high \\
\hline 5 & 3 & 8 & Raised from very high \\
\hline 5 & 4 & 8 & Raised from very high \\
\hline 5 & 6 & 9 & Significantly raised from very high \\
\hline 5 & 9 & 9 & Significantly raised from very high \\
\hline
\end{tabular}

Table 6 Outputs from combining the shrink swell and climate score grids

It is recognised that this is a relatively straightforward approach and that more detail and levels of susceptibility could be added. However, more detailed outputs may suggest a more complex model and it is recognised that this model has many areas that can be refined, as detailed in Section 7. 
To gain an understanding of the model outputs and aid model refinement, the historical station data were input into the calculations described in the Section 4.1 model (Table 6) and the resulting values were plotted on a graph for the years for which data were available, and shown against the subsidence claims data.

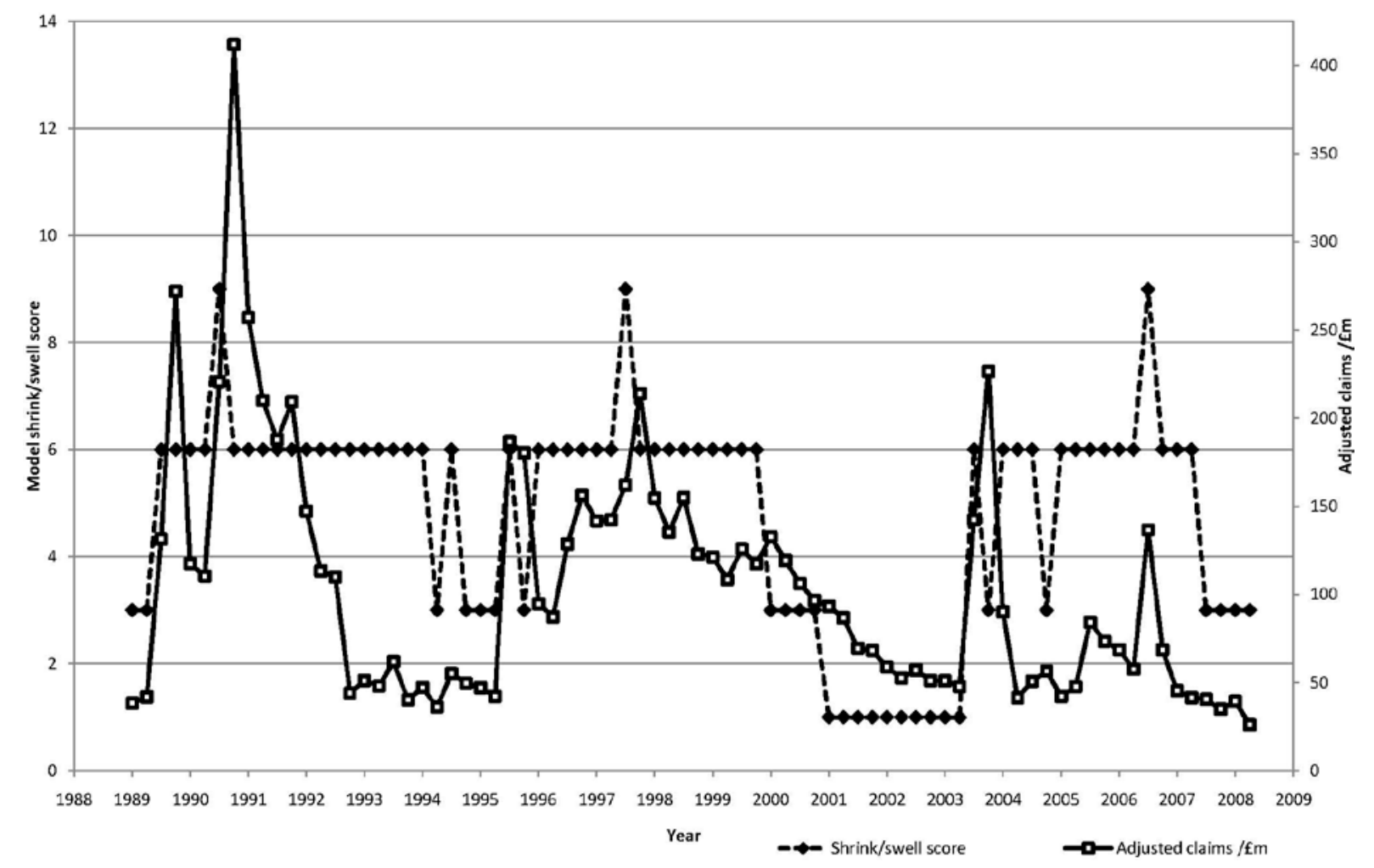

Figure 10 Initial model output using historical meteorological station data compared with subsidence claims data

To improve the accuracy of the resulting model, various refinements were tested. One refinement tested was to weight the temperature value to have more influence with any temperature above $22.6^{\circ} \mathrm{C}$ leading to a resulting model output of 9 (see Table 6). Another tested was multiplying the rainfall and temperature scores rather than adding them together and therefore altering the output climate scores produced. However, neither of these improved the correlation with adjusted claims. However, varying the rainfall threshold values did demonstrate that the model could be refined to improve correlation (see Table 7 and Figure 11). 


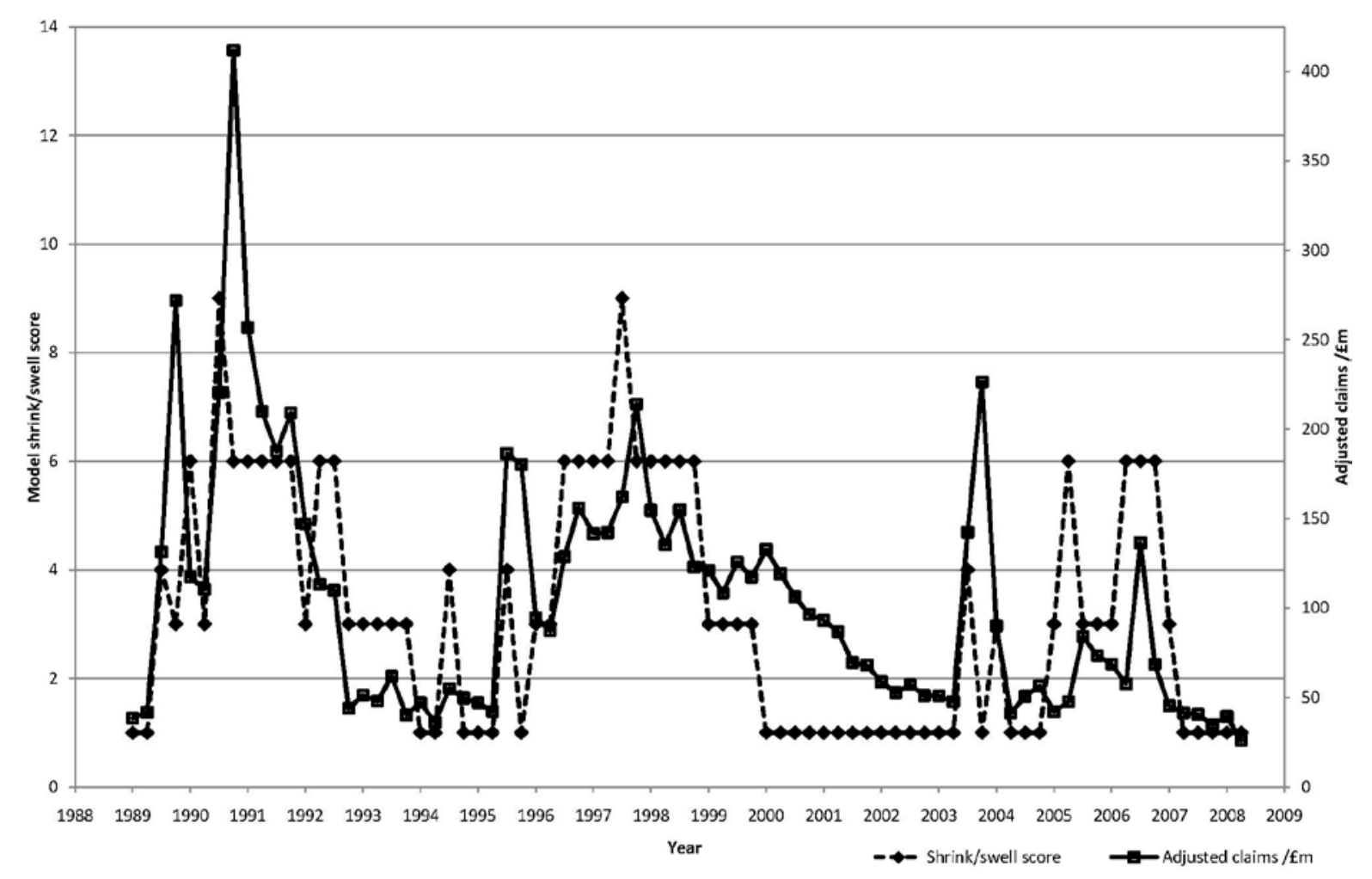

Figure 11 Modified model output using historical meteorological station data compared with subsidence claims data

Following small alterations in the two rainfall threshold values, above 394mm being low potential and below $350 \mathrm{~mm}$ being high potential, and maintaining the temperature threshold value at $22.6^{\circ} \mathrm{C}$, the best correlation with subsidence claims data was produced (Figure 11). These final values are summarized in Table 7, with the initial threshold values also shown. This shows the slight decrease in 8 quarters of rainfall required for high and medium potential to occur.

\begin{tabular}{|c|c|c|}
\hline Parameter & Initial Threshold Value & Final Threshold Value \\
\hline Rainfall (high potential) & $\begin{array}{c}\text { Below 400mm for the last } 8 \\
\text { quarters }\end{array}$ & $\begin{array}{c}\text { Below 350mm for the last } 8 \\
\text { quarters }\end{array}$ \\
\hline Rainfall (low potential) & $\begin{array}{c}\text { Above } 450 \mathrm{~mm} \text { for the last } 8 \\
\text { quarters }\end{array}$ & $\begin{array}{c}\text { Above 394mm for the last } 8 \\
\text { quarters }\end{array}$ \\
\hline $\begin{array}{c}\text { Rainfall (medium potential) } \\
\text { potential) }\end{array}$ & $\begin{array}{c}\text { Between } 400 \text { and } 450 \mathrm{~mm} \text { for } \\
\text { the last } 8 \text { quarters }\end{array}$ & $\begin{array}{c}\text { Between } 350 \text { and } 394 \mathrm{~mm} \text { for } \\
\text { the last } 8 \text { quarters }\end{array}$ \\
\hline $\begin{array}{c}\text { Temperature (low potential) } \\
\text { Above } 22.6^{\circ} \mathrm{C} \text { for } 1 \text { quarter }\end{array}$ & $\begin{array}{c}\text { Above } 22.6^{\circ} \mathrm{C} \text { for } 1 \text { quarter } \\
\text { (no change) }\end{array}$ \\
\hline Below $22.6^{\circ} \mathrm{C}$ for 1 quarter & $\begin{array}{c}\text { Below 22.6 }{ }^{\circ} \mathrm{C} \text { for } 1 \text { quarter } \\
\text { (no change) }\end{array}$ \\
\hline
\end{tabular}




\section{Table 7 Final model threshold values, and the initial thresholds shown for comparison}

\subsection{Statistical analysis}

A statistical analysis of the initial and refined models was carried out to quantify them and assess the refinement by more than the graph alone appearing to show a closer correlation with subsidence claims.

The relationship between the quarterly adjusted claims and corresponding shrink-swell index (initial and refined) was investigated by linear mixed models in which adjusted claims was the dependent variable, shrink-swell index was the fixed effect and the residual was modelled as a temporally correlated random effect. This was done using the nlme library (Pinheiro et al., 2010) in the R platform (R Development Core Team., 2010). It was necessary to transform adjusted claims to logarithms to ensure that the residuals had a reasonably symmetrical distribution. In both cases (initial and refined swell-shrink index) the residuals from the model were found to show significant temporal autocorrelation. An approximate adjusted coefficient of determination $\left(\mathrm{R}^{2}\right)$ value was computed for the two models (with initial and refined swell-shrink index as the respective predictors). This was computed as

$$
\mathrm{R}_{\text {adj }}^{2}=1-\mathrm{s}_{\mathrm{m}}{ }^{2} / \mathrm{s}^{2},
$$

where $\mathrm{s}_{\mathrm{m}}{ }^{2}$ is the residual variance for the fitted model, and $\mathrm{s}^{2}$ is the residual variance for a model with the only fixed effect being the overall mean of the (log-transformed) adjusted claims. The values of $\mathrm{R}^{2}$ adj for the models with the initial and refined indices as predictors are 0.16 and 0.26 respectively. As the coefficient of determination ranges from 0 to 1 , and provides a value for the proportion of variability in the data that is accounted for by the model, this shows that there is some improvement achieved by the refinement of the swellshrink index, but there is still substantial variation in the claims values to be explained through improved modelling.

\subsection{Constructing the model - combining with GeoSure}

The resulting climate scores produced by the combination of temperature and rainfall (for examples see Figure 12 and Figure 13) were then combined with GeoSure values as outlined in Table 6 to provide a susceptibility classification. This combination with GeoSure allows the rules to be applied to the larger Model Area and scenarios to be constructed for south-east England, as shown in Figure 14 to Figure 17. 


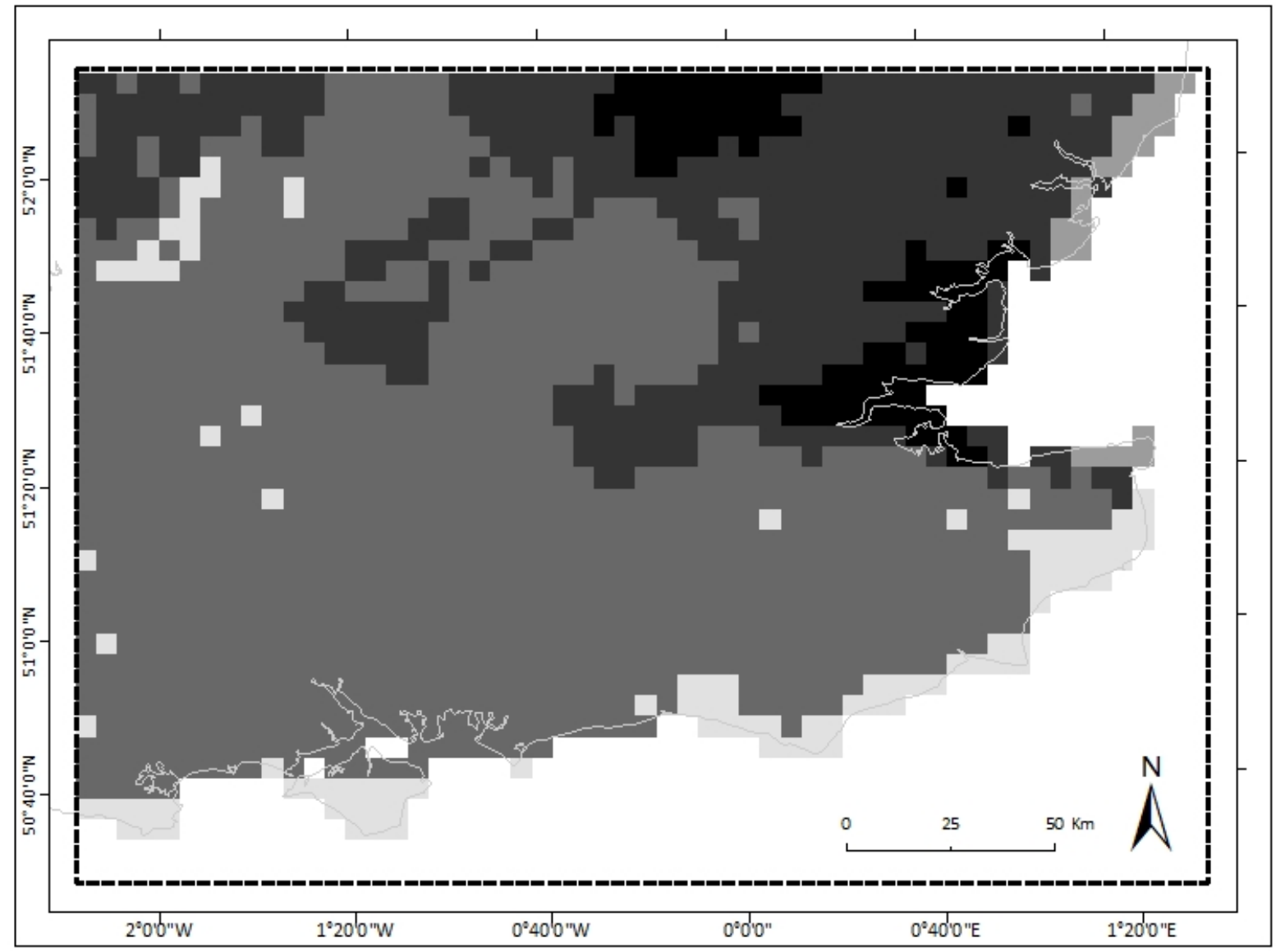

Climate Score (Low emissions scenario 2080s)

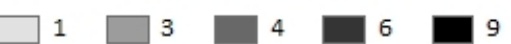

Figure 12 2080s low emissions scenario climate score output grid

BGS (C) NERC All rights reserved. Contains public sector information licensed under the Open Government Licence v1.0. (C) UKCIP 2011 


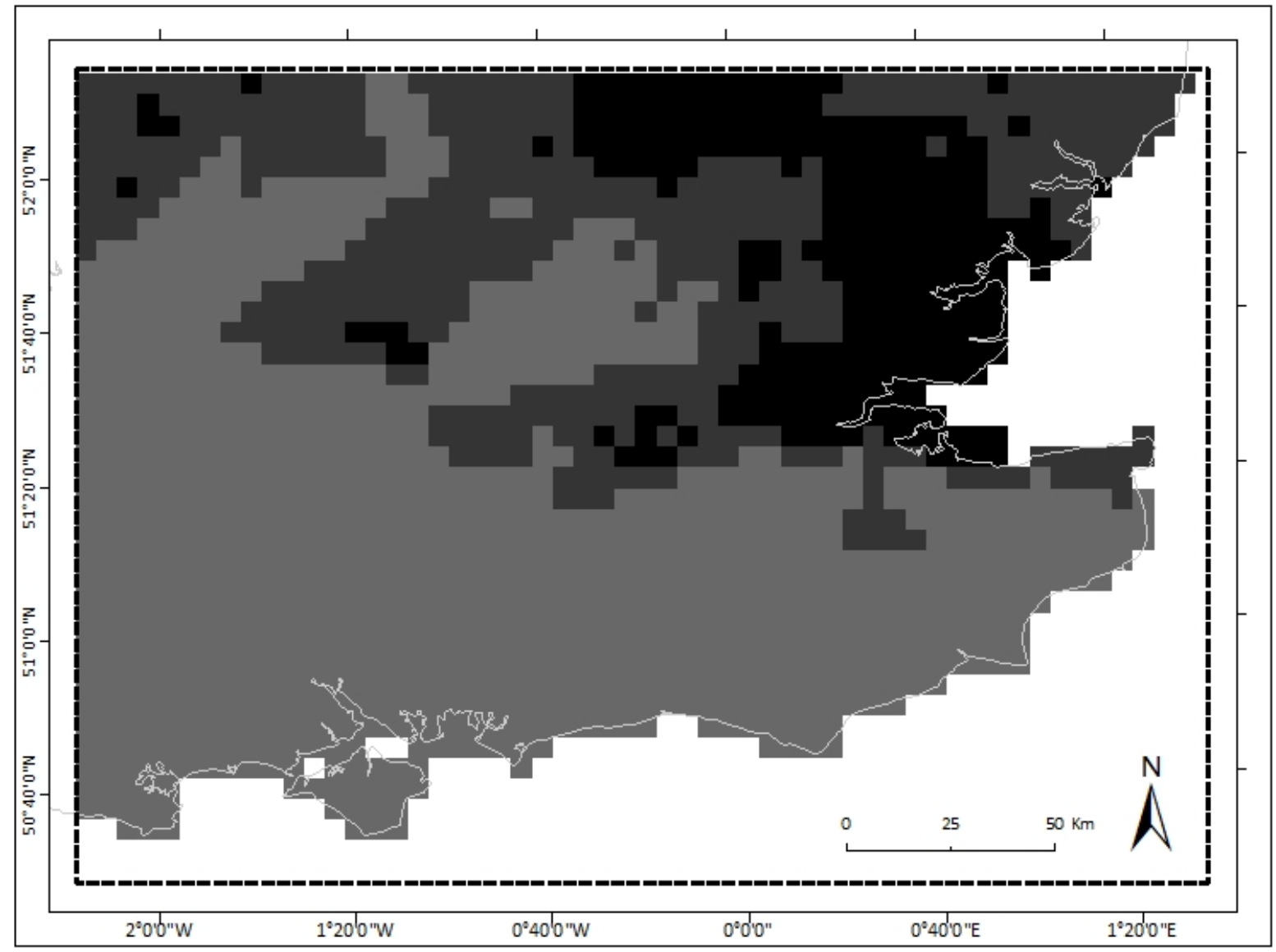

Climate Score (High emissions scena rio 2080s)

$4 \square 6$

\section{Figure 13 2080s high emissions scenario climate score output grid}

BGS @ NERC All rights reserved. Contains public sector information licensed under the Open Government Licence v1.0. ๑ UKCIP 2011 


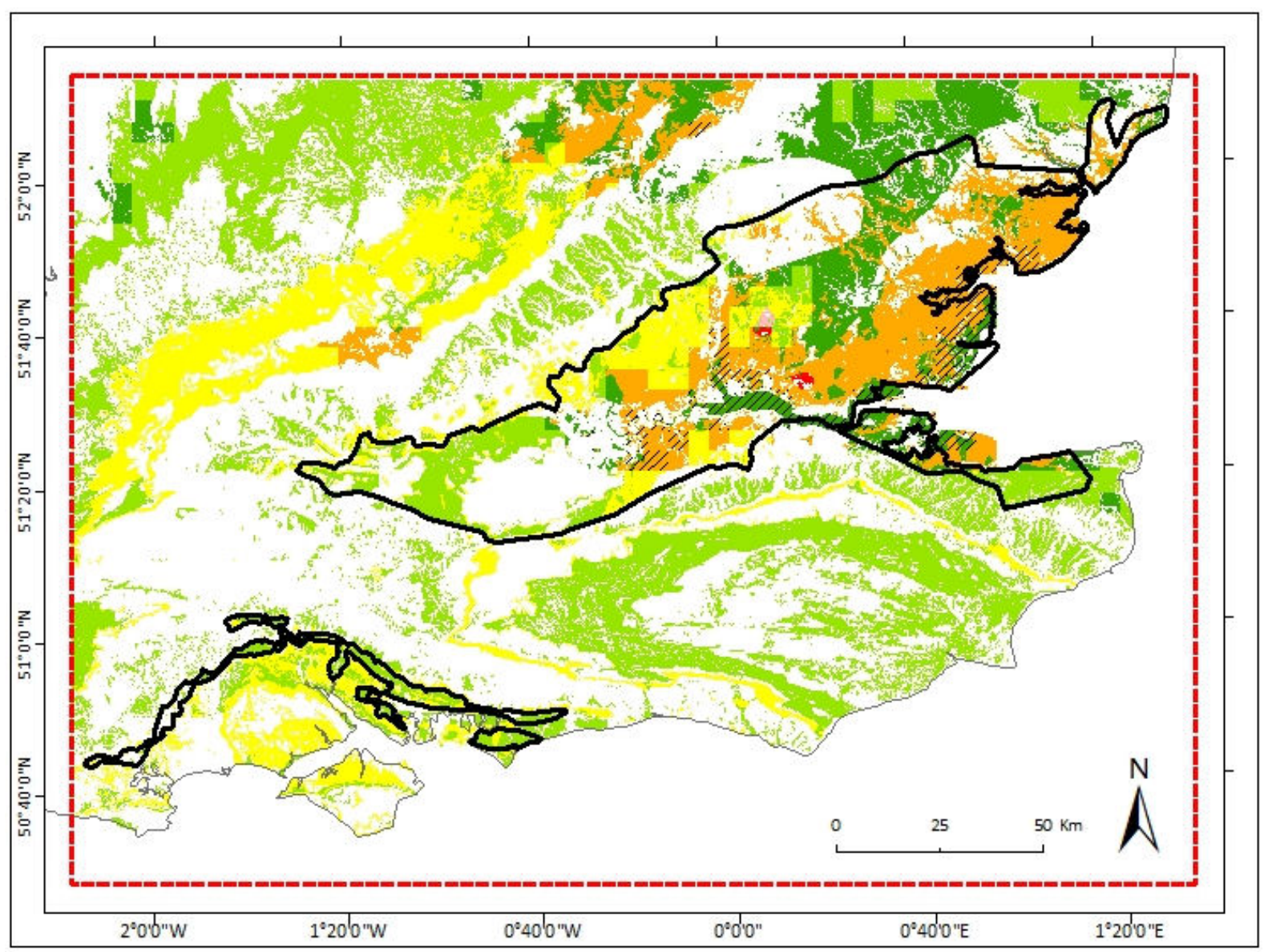

London Clay

Subsidence susceptibility (Low emissions scenario 2020s)

\begin{tabular}{|c|c|c|}
\hline Medium & High & Very high \\
\hline Slightly more vulnerable & Slightly more vulne rable & Slightly more vulne rable \\
\hline Much more vulnerable & Much more vulne rable & Much more vulnerable \\
\hline
\end{tabular}

Figure 14 Subsidence susceptibility classification (low emissions 2020s)

BGS ( ) NERC All rights reserved. Contains public sector information licensed under the Open Government Licence v1.0. ( UKCIP 2011 


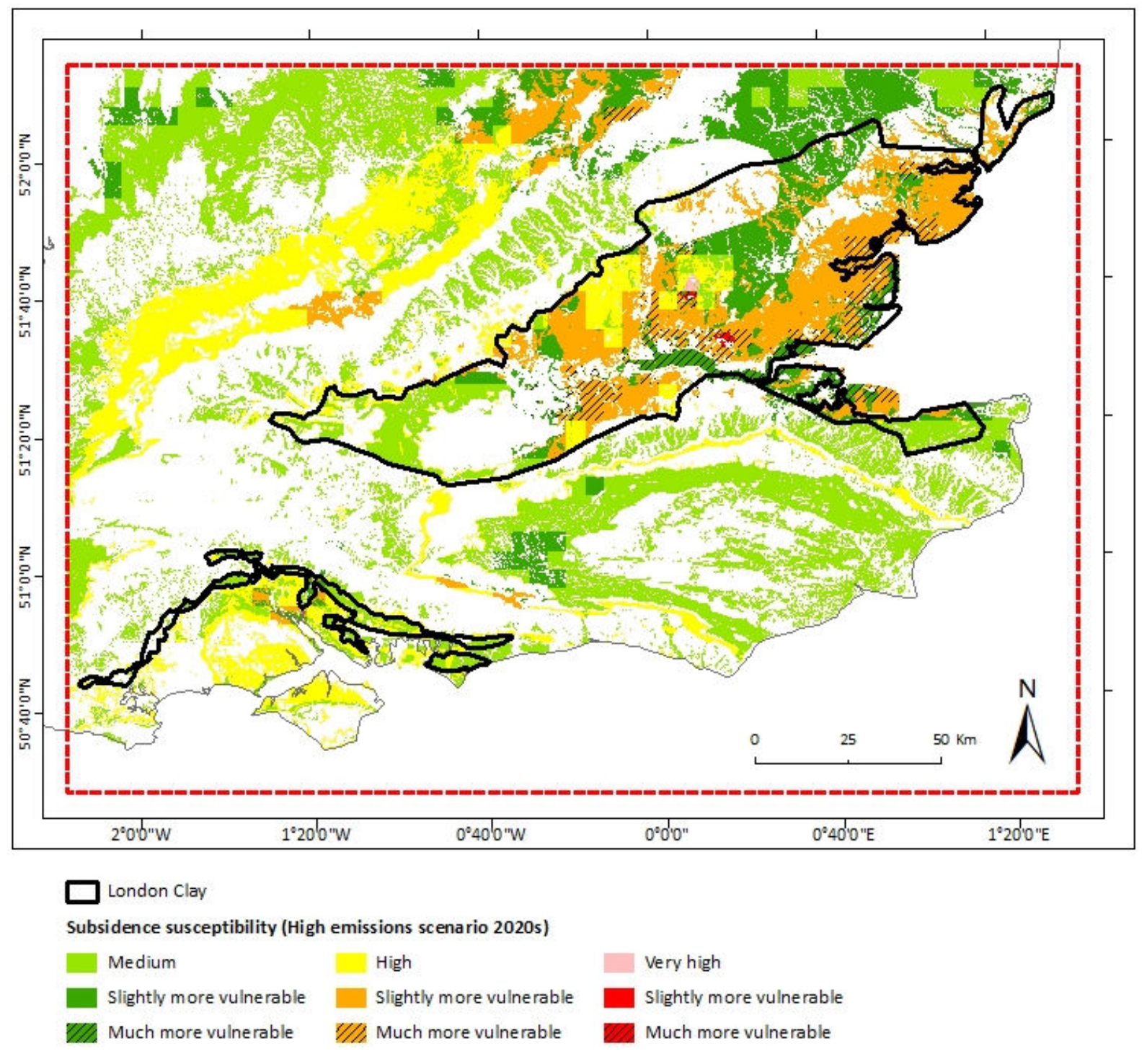

Figure 15 Subsidence susceptibility classification (high emissions 2020s)

BGS $\odot$ NERC All rights reserved. Contains public sector information licensed under the Open Government Licence v1.0. ๑ UKCIP 2011 


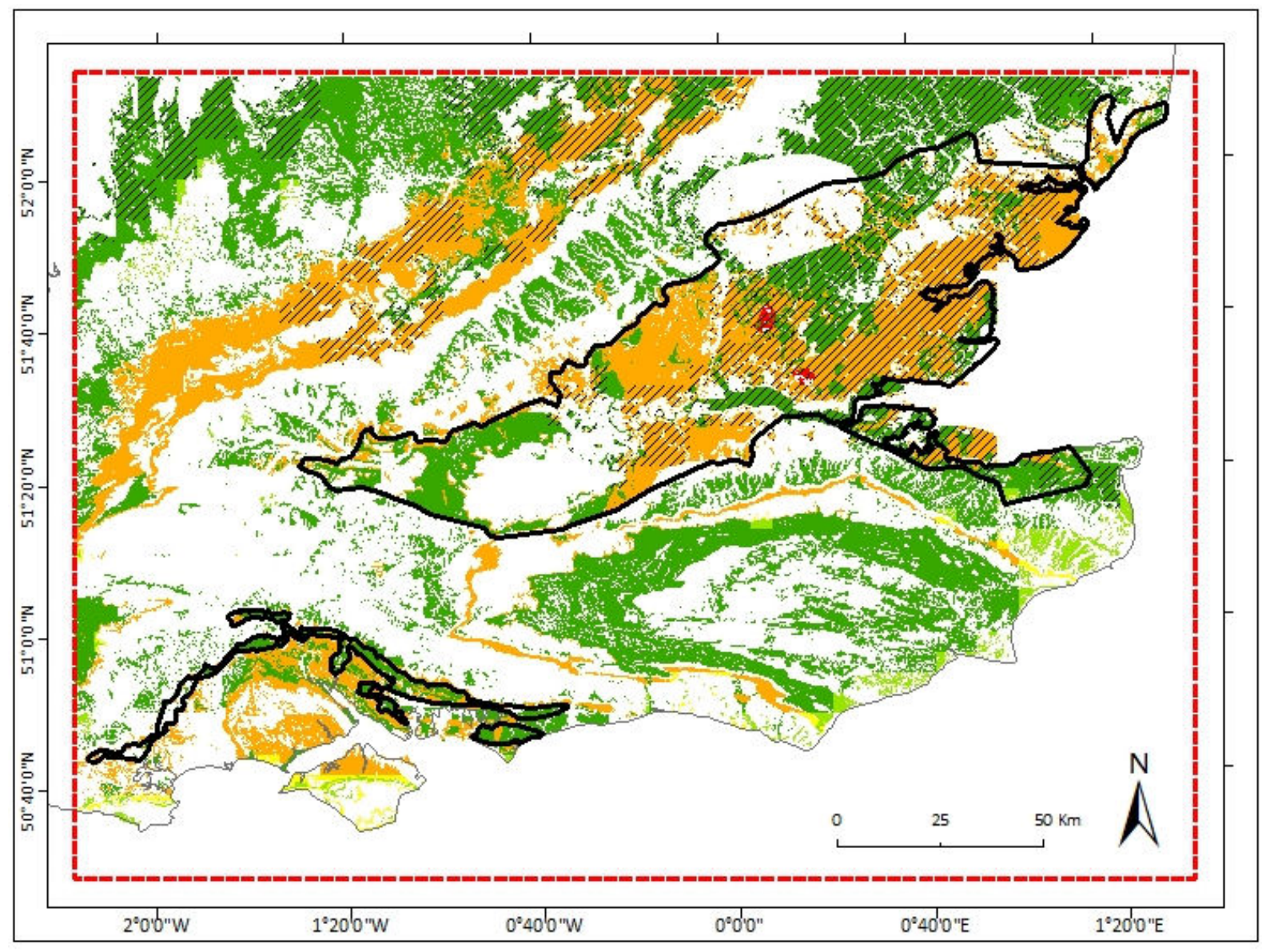

London Clay

Subsidence susceptibility (Low emissions scenario 2080s)

$\begin{array}{lll}\text { Medium } & \text { High } & \text { Very high } \\ \text { Slightly more vulnerable } & \text { Slightly more vulnerable } & \text { Slightly more vulne rable } \\ \text { WhA Much more vulnerable } & \text { W/A Much more vulnerable } & \text { Much more vulnerable }\end{array}$

Figure 16 Subsidence susceptibility classification (low emissions 2080s)

BGS $\odot$ NERC All rights reserved. Contains public sector information licensed under the Open Government Licence v1.0. ๑) UKCIP 2011 


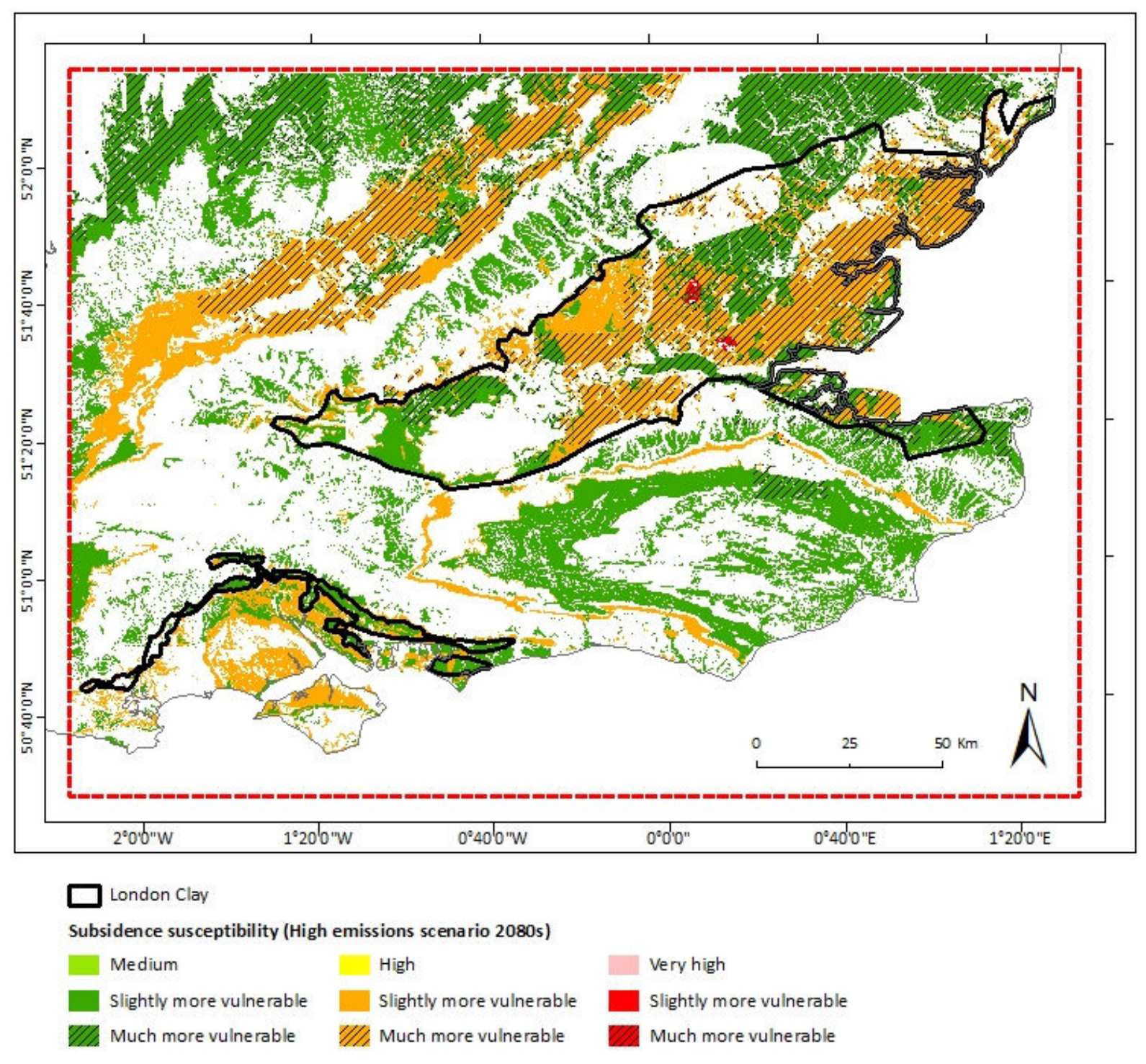

Figure 17 Subsidence susceptibility classification (high emissions 2080s)

BGS $\odot$ NERC All rights reserved. Contains public sector information licensed under the Open Government Licence v1.0. ๑ UKCIP 2011

Based on the refined model conditions, the combined climate score grid for the 2080s low emissions scenario contained susceptibility classification values of 1, 3, 4, 6, and 9 (as described in Table 8) across the model area (Figure 12). For the 2080s high emissions scenarios susceptibility classification values of 4, 6, and 9 were applied across the area (Figure 13). For the 2020s the climate score across the study area is more varied with susceptibility classification values of 1, 3, 4, and 6 for the low emissions scenario and 1, 3, 4, 6, and 9 for the high emissions scenario. Large areas of both the low and high emissions scenarios climate score grids for the 2020s were given a score of 1 .

\subsection{Effect of climate change elsewhere in the model area}

The most noticeable changes in susceptibility can be seen within the London Clay area. Other geological formations within the model area (Figure 4) showing susceptibility to shrink-swell include the Kimmeridge Clay, the Oxford Clay, the Gault, the Wealden Group and clays of 
the Lambeth Group (Driscoll, 1983). Due to the high clay content and mineralogy of these deposits, and thus their high GeoSure shrink-swell susceptibility, these are the areas that would be expected to show the highest susceptibility change in the future.

Some clay-rich Quaternary (superficial) deposits are also susceptible to shrink-swell. Some areas with glacial till overlying the bedrock geology, will have a shrink-swell GeoSure value reflecting this, due to the higher clay content of some of the tills.

The resulting maps (Figure 14 to Figure 17), summarised in Table 8, provide a projection of subsidence occurrence in the future, based on low and high emissions scenarios. These classifications are presented as changes from present day shrink swell susceptibility, provided by GeoSure, which assumes current ‘baseline’ climatic conditions.

\begin{tabular}{|r|l|r|r|r|r|}
\cline { 3 - 6 } \multicolumn{2}{c|}{ Value } & \multicolumn{5}{|c|}{ Area in resulting model (\%) } \\
& Classification & $\begin{array}{c}\text { Low 2020 } \\
\text { scenario }\end{array}$ & $\begin{array}{c}\text { High 2020 } \\
\text { scenario }\end{array}$ & $\begin{array}{c}\text { Low 2080 } \\
\text { scenario }\end{array}$ & $\begin{array}{c}\text { High 2080 } \\
\text { scenario }\end{array}$ \\
\hline 1 & Medium (no change) & 47.17 & 44.44 & 2.37 & 0.00 \\
\hline 2 & Raised from medium & 11.98 & 14.43 & 37.51 & 31.79 \\
\hline 3 & Significantly raised from medium & 1.75 & 2.03 & 21.02 & 29.11 \\
\hline 4 & High (no change) & 23.37 & 21.17 & 0.73 & 0.00 \\
\hline 5 & Raised from high & 12.90 & 13.95 & 20.05 & 14.16 \\
\hline 6 & Significantly raised from high & 2.66 & 3.81 & 18.15 & 24.77 \\
\hline 7 & Very high (no change) & 0.08 & 0.08 & 0.00 & 0.00 \\
\hline 8 & Raised from very high & 0.09 & 0.00 & 0.00 & 0.00 \\
\hline 9 & Significantly raised from very high & 0.00 & 0.09 & 0.17 & 0.17 \\
\hline & Total percentage & 100 & 100 & 100 & 100 \\
\hline
\end{tabular}

Table 8 Resulting areas of the susceptibility classifications within the model area

\section{$6.22020 s$}

Low emissions scenario

The results for the 2020s low emissions scenario (Figure 14) suggest that about $29 \%$ of the area will have a raised or significantly raised susceptibility to shrink swell, compared to present day. The areas that demonstrate potential change are around central London and coastal areas from Southend to Orford Ness.

High emissions scenario

The general areas showing change with the high emissions scenario (Figure 15) are not dissimilar to those for the low emissions scenario. The boundaries have expanded slightly and the area with increased susceptibility now being around 34\% of the area. The fundamental difference appears to be that the amount of change experienced within these areas has increased. For example, two small patches of London Clay show 'raised from very high' for the low emissions scenario, but for the high emissions scenario show 'significantly raised from very high.' 
Low emissions scenario

The results for the 2080s low emissions scenario (Figure 16) suggest that nearly all of the area will have an increased susceptibility to shrink-swell, with as little as $4 \%$ of the area remaining unchanged.

High emissions scenario

$100 \%$ of the clay-rich susceptible units have significantly risen from high levels of susceptibility based on the 2080's high emissions scenario (Figure 17). Many areas have increased from raised to significantly raised susceptibility compared with the low emissions scenario map. This has caused areas with 'significantly raised' susceptibility on the 2080s low emissions scenario map to expand in size. 


\section{DISCUSSION}

The number of insurance subsidence claims has shown a general increase during the last 30 years (Figure 2). Figure 6 to Figure 9 show that the level of subsidence claims is, at least, partly controlled by climate. Comparison with Met Office historical climate data (Figure 2) reveals that, since 1984, climatic conditions show increased variability and increased frequency of extreme wet and dry periods; the latter increases the likelihood of shrink-swell (Pugh, 2002). Other non-climatic controlling factors have been recognised, such as the state of the economy and society attitude (Biddle, 1979; Rex and Thomas, 2007) and, on a site specific basis, the proximity and type of vegetation and trees (Biddle, 1983; Driscoll, 1983).

The large cost to society of shrink-swell hazard associated with climatic conditions is contrasted by a general lack of concepts to assess the risk associated with this hazard (Corti et al., 2009). Little research into the relationship between shrink-swell incidence and changing climate has been published. The relationship between shrink-swell and climate (temperature and precipitation) has been noted by many (Pugh, 2002), but much of subsidence research in the UK has been into the geological or constructional aspects e.g. (Crilly, 2001; Driscoll, 1983).

A previous study in France that modelled climate and shrink-swell incidence, utilised similar datasets to act as proxies (Corti et al., 2009). For example, damage data (monetary value) were used to represent shrink-swell incidence. These authors also utilised observed monthly mean temperature, and precipitation, gridded datasets. The present study supports the conclusions of Corti et al., (2009) that there is a strong meteorological influence on the interannual variability in soil subsidence variability.

Other research suggests that relatively rapid increases in the number of subsidence claims can occur with little or no warning, irrespective of the antecedent soil moisture conditions (Pugh, 2002). In contrast, the results described here suggests that overall patterns in claims are controlled by antecedent rainfall but that rapid increases in the number of claims seem to be related to increased temperatures. Pugh (2002) stated that a rapid claims increase could be produced by a cumulative rainfall deficit and could still occur even if the ground had been fully replenished by a period of rainfall. Pugh (2002) went on to state that it was not considered possible to predict a rapid claims increase based on soil moisture replenishment alone. More research is required to better understand these complex relationships.

Crilly (2001) identified the London Clay Formation as the most commonly encountered 'problem' engineering soil in Greater London (because it underlies much of urban London). Not only was it the geological formation most affected by shrinkage due to vegetation growth, and heave due to vegetation removal, it was also the formation identified as being most affected by seasonal clay shrinkage and swelling. The model outputs presented here confirm that the main geological area showing increased susceptibility is the London Clay Formation, with other units within the model area being affected including Gault Clay, Weald Clay, Kellaways and Oxford Clay Formations, the Kimmeridge Clay, and clays of the Lambeth Group (Figure 4). 
Glacial till, located in the north of the model area, also plays a role in affecting shrink-swell occurrence, due to its high clay content. In contrast, also within the model area, are areas overlain with Thames terrace gravels, making these areas less susceptible to shrink-swell as these deposits have good drainage properties and a low clay content (Bridgland et al., 1994).

This research suggests increased cases of subsidence affecting domestic buildings within much of the London area by 2020 based on the high emissions climate scenario. This is less than 10 years in the future and is an indication of the potential effects that a variable climate could have on this issue in the not too distance future.

The ability to predict future trends and, in particular rapid increase in claims, is likely to be of benefit to insurers' resource planning. It is also important for the planning of new builds and identifying the types of foundations required to prevent shrink-swell subsidence.

The issue of soil depths affected by swell-shrink is a complex one. Based on research by BRE in the 1940 and 1950s, in areas with minor vegetation the recommended foundation depth was $0.9 \mathrm{~m}$. Anon (2011) recommended a minimum of $1.0 \mathrm{~m}$. However, the presence of trees of different types affects this depth. According to Anon (2011) for soils of high shrinkability (that is with a plasticity index greater than $40 \%$ ) with trees of high water demand close to the proposed building, the recommended minimum foundation depth can be as great as $3.5 \mathrm{~m}$. Claims data (our proxy) does not distinguish the age of the house and, hence, the depth of foundation that can be inferred. However, it is probably true to say that subsidence is more likely to affect pre 1970s houses but particularly those houses built before proper dug foundations were required.

A good understanding of the threats of climate change to our buildings, and the potential levels of damage and cost, is important to mitigate the risks.

Further research is still needed to expand the ideas developed in this paper. The following topics are suggested:

1) Detailed statistical analysis to identify the mathematical relationship between previous year's rainfall, temperature and subsidence claims.

2) Further analysis of the close relationship between rainfall and temperature to identify an intelligent method of combining them in a refined model.

3) Further interpretation of monthly rainfall and temperature data, thus avoiding 'smoothing' that may be occurring by analysing the data in quarterly periods.

4) Detailed examination of the yearly claims data from 1975 onwards and how it can be utilised to refine the model.

5) Identification and utilisation of a soil moisture deficit dataset derived from in situ measurements, potentially replacing rainfall and temperature, currently being utilised as proxies. 
6) Overcoming the formatting and resolution issues encountered using the UKCP09 precipitation and rainfall datasets, thus allowing more robust and recent data to be used. UKCP09 shows a range of possible outcomes and the probability of each outcome, based on how much evidence there is for different levels of future climate change. UKCP09 maps for each grid square show a value based on a given relative likelihood (probability level) of the change being at or below that value. (UKCIP, 2009b). Therefore, these data are therefore presented in a totally different format from the UKCIP02 dataset and modifications to the model would be required. However, the benefit of advancements in climate modelling and computer science lead to UKCP09 being a valuable dataset deserving further investigation to improve compatibility with the GeoSure and claims datasets to allow analysis.

7) Use of changes in rainfall data, not only actual rainfall of previous years. Investigation of whether there is a relationship between longer periods of decreasing rainfall and hence soil moisture levels, and shrink-swell occurrence.

8) Enlargement of the model geographically to match GeoSure (Great Britain).

9) Analysis of not just the sum of previous rainfall, but extreme droughts and wet periods which could lead to desiccation cracks in clay-rich soils. Forster et al., (2009) have discussed this in detail.

10) Laboratory investigations of shrink-swell - research into changes in the properties of clay at the temperatures $22.6^{\circ} \mathrm{C}$ and $25.5^{\circ} \mathrm{C}$ (the mean and maximum temperatures associated with peaks in subsidence claims), to better understand the controlling processes.

11) Analysis using a varying climatic dataset (temperature and rainfall) across the test area for the observed model.

12) Analysis including housing data in the model, such as housing density.

13) More detailed analysis of the controls on the size of the peaks of rapid claims increases. 


\section{CONCLUSIONS}

This study has highlighted the potential value of the subsidence claims dataset as a proxy for shrink-swell geohazard in the UK based on a study of the south east of England, encompassing most of the area underlain by the London Clay.

Although other researchers have identified that precipitation has a strong relationship with shrink-swell, the research described here has demonstrated that precipitation and temperature are working together to influence the number and value of subsidence claims.

Analysis has shown that two years (8 quarters) of precipitation data and the quarterly mean maximum temperature (TMAX) data combined together can be used to model increases and decreases in subsidence claims and, thus, the severity of shrink-swell occurrence. A quarterly mean maximum temperature 'tipping point', of $22.6^{\circ} \mathrm{C}$, has been identified; a temperature above which the associated adjusted claims data shows a peak in claims that cannot be modeled by the rainfall data alone. This suggests that a quarter (3 months) of warmer weather, with the maximum temperature for each of the 3 months used to provide a mean TMAX for the quarter, leads to an increase in shrink-swell occurrence. This relationship with temperature acts alongside the underlying long term (two years) rainfall relationship. This analysis provides a more detailed understanding of the dependency of shrink-swell occurrence on rainfall and temperature, than was previously held.

The UKCIP02 2020s projection modeling for the high emissions climate scenario suggests that there will be larger areas of Great Britain with 'raised' and 'significantly raised' susceptibility to shrink-swell, compared with the low emissions climate scenario. The 2080s projection, even following the low emissions climate scenario, suggests that almost all the area with clay-rich formations will show an increased susceptibility. For the high emissions climate scenario, there is a larger area showing significant increase from either low or medium susceptibility, with the whole model area experiencing a general rise in susceptibility.

The limitations of this model are recognized. This is a start point of this type of analysis, with many necessary assumptions. Areas of future research have been highlighted to enable refinement of the model.

Future developments and refinements of this model could eventually lead to the model becoming a predictive tool. Recent rainfall and temperature data would be required to anticipate upcoming peaks and troughs in shrink-swell occurrence. The knowledge gained and the increased understanding of the effects of a changing climate on ground conditions, could aid decision making to mitigate against risk.

\section{ACKNOWLEDGEMENTS}

Permission to publish by BGS staff is granted by the Executive Director, British Geological Survey (NERC). The authors wish to thank Murray Lark (British Geological Survey) for his support with the statistical analysis. 
ABI, 2009. Association of British Insurers webpage http://www.abi.org.uk/.

Anon, 1980. Low-rise buildings on shrinkable clay soils: Part 2. BRE Digest 241 Building Research Establishment, Garston, Watford.

Anon, 1988. Prevention of foundation failures in new dwellings. National House-Building Council, London.

Anon, 1993a. Low-rise buildings on shrinkable clay soils: Part 1. BRE Digest 240. Building Research Establishment, Garston, Watford.

Anon, 1993b. Underpinning. Digest 352, Building Research Establishment, Garston, Watford.

Anon, 1999. The influence of trees on house foundations in clay soils. Digest 298., Building Research Establishment, Garston, Watford.

Anon, 2011. NHBC Standards Chapter 4.2 Building near trees. National House-Building Council, London.

Biddle, P.G., 1979. Tree root damage to buildings - an arboriculturists experience. Arboricultural Journal 3, 6, 397-412.

Biddle, P.G., 1983. Patterns of soil drying and moisture deficit in the vicinity of trees on clay soils. Géotechnique 33, 107-126.

Bridgland, D.R., Bowen, D.Q., Wimbledon, W.A., 1994. Quaternary of the Thames, 1st ed. Chapman \& Hall, London.

Corti, T., Muccione, V., Kollner-Heck, P., Bresch, D., Seneviratne, S.I., 2009. Simulating past droughts and associated building damages in France. Hydrology and Earth System Sciences, 13, 1739-1747.

Crilly, M., 2001. Analysis of a database of subsidence damage. Structural Survey 19, 7-15.

Driscoll, R., 1983. The influence of vegetation on the swelling and shrinking of clay soils in Britain. Géotechnique 33, 93-105.

Driscoll, R., Skinner, H., 2007. Subsidence Damage to Domestic Buildings. A good guide to Technical practice. Publication FB13. BREPress, London.

Forster, A., Culshaw, M.G., Wildman, G., Harrison, M., 2009. Implications of climate change for urban areas in the UK from an engineering geological perspective, In: Culshaw, M.G., Reeves, H.J., Jefferson, I., Spink, T.W. (Eds.), Engineering geology for tomorrow's cities, Geological Society, London, Engineering Geology Special Publication 22 , CD paper number 246. 
Harrison, A.M., Harrison, M., Plim, J., Culshaw, M.G., Jones, L.D., 2010. UK regional scale modelling of natural geohazards and climate change, In: Williams, A.L., Pinches, G.M., Chin, C.Y., McMorran, T.J., Massey, C.I. (Eds.), Proceedings of the 11th Conference of the International Association of Engineering Geology and the Environment. CRC Press/Balkema, Auckland, New Zealand, 1163-1169.

Harrison, M., Foster, A., 2003. The application of GIS modelling to the assessment of geohazard potential at a national scale. In: Proceedings of the 2003 Annual Conference of the International Association for Mathematical Geology (IAMG). International Association of Mathematical Geology, Portsmouth, UK.

Harrison, M., Jones, L.D., Gibson, A.D., Cooper, A.H., Wildman, G., Foster, C., 2009. GeoSure Version 5. Methodology Review: Shrink Swell. Technical Report IR/08/092. British Geological Survey, Keyworth, Nottingham.

Hobbs, P.R.N., Jones, L.D., 1998. The shrinkage and swelling behaviour of UK soils: the Gault Clay. Technical Report WN/98/13. British Geological Survey, Keyworth, Nottingham.

Hobbs, P.R.N., Jones, L.D., 2000. Clay shrinkage research at the British Geological Survey. Slips, Shrinks, and Swells - Clay Minerals \& Geotechnics., Joint Meeting of the Clay Minerals Group of the Mineralogical Society and Engineering Group of the Geological Society, Keyworth, Nottingham.

Hobbs, P.R.N., Jones, L.D., Freeborough, K., 2007. The shrinkage and swelling behaviour of UK rocks and soils: the Lias Group. Technical Report IR/07/032. British Geological Survey, Keyworth, Nottingham.

Hulme, M., Jenkins, G.J., Lu, X., Turnpenny, J.R., Mitchell, T.D., Jones, R.G., Lowe, J., Murphy, J.M., Hassell, D., Boorman, P., McDonald, R., Hill, S., 2002. Climate Change Scenarios for the United Kingdom: The UKCIP02 Scientific Report. Tyndall Centre for Climate Change Research, School of Environmental Sciences, Univeristy of East Anglia, Norwich, UK, 120p.

Hunt, R., Dyer, R.H., Driscoll, R., 1991. Foundation movement and remedial underpinning in low-rise buildings. Report BR 184, Building Research Establishment, Garston, Watford.

Jones, L.D., 2002. Shrinking and Swelling Soils in the UK: Assessing clays for the planning process., Earthwise, Issue 18. British Geological Survey, 22-23.

Jones, L.D., 2004. Cracking open the property market, Planet Earth, Autumn Edition, 30-31.

Jones, L.D., Hobbs, P.R.N., 1998. The shrinkage and swelling behaviour of UK soils: the clays of the Mercia Mudstone Group. Technical Report WN/98/14. British Geological Survey, Keyworth, Nottingham.

Jones, L.D., Hobbs, P.R.N., 2005. The shrinkage and swelling behaviour of UK soils: the clays of the Lambeth Group. Research Report RR/04/001. British Geological Survey, Keyworth, Nottingham. 
Jones, L.D., Jefferson, I., 2012. Expansive soils. In: Burland, J., Chapman, T., Skinner, H., Brown, M. (Eds.), ICE manual of geotechnical engineering. Volume 1 Geotechnical engineering principles, problematic soils and site investigation. ICE Publishing, London, 413441.

Jones, L.D., Terrington, R., 2011. Modelling volume change potential in the London Clay. Quarterly Journal of Engineering Geology and Hydrogeology 44, 109-122.

Madden, R.A., Williams, J., 1978. The correlation between temperature and precipitation in the United States and Europe. Monthly Weather Review 106, 142-147.

Met Office, 2009. Historic station data http://www.metoffice.gov.uk/climate/uk/stationdata/.

Met Office, 2011. Regional climates http://www.metoffice.gov.uk/climate/uk/regional/.

Pinheiro, J., Bates, D., DebRoy, S., Sarkar, D., Team, R.D.C., 2010. nlme: Linear and nonlinear mixed effects models. $\mathrm{R}$ package version 3.1-97.

Pugh, R.S., 2002. Some observations on the influence of recent climate change on the subsidence of shallow foundations. Proceedings of the Institution of Civil Engineers Geotechnical Engineering 155, 23-25.

R Development Core Team., 2010. R: A language and environment for statistical computing. R Foundation for Statistical Computing, Vienna, Austria. ISBN 3-900051-07-0, URL http://www.R-project.org/.

Rex, G., Thomas, R., 2007. Clay desiccation demystified. Special Interest Group Subsidence. The Chartered Institute of Loss Adjusters (CILA), London.

Royse, K.R., De Freitas, M., Burgess, W.G., Cosgrove, J., Ghail, R.C., Gibbard, P., King, C., Lawrence, U., Mortimore, R.N., Owen, H., Skipper, J., 2011. Geology of London, UK. Proceedings of the Geologists' Association 123, 22-45.

UKCIP, 2002. UKCIP02 climate change scenarios webpages.

UKCIP, 2009a. UK Climate Impacts Programme website.

UKCIP, 2009b. UK Climate Projections (UKCP09).

Walsby, J.C., 2007. Geohazard information to meet the needs of the British public and government policy. Quaternary International 171-172, 179-185.

Walsby, J.C., 2008. Geosure : a bridge between geology and decision making In: Liverman, D.G.E., Pereira, C.P.G., Marker, B. (eds), Communicating environmental geoscience. Geological Society, London, Special Publications, 305, 81-87.

Wyles, R., 1983. The legal aspects of the influence of vegetation on the swelling and shrinking of clays. Géotechnique 33, 89-91. 